\title{
Diverse realities: Understanding sexually transmitted infections and HIV in India
}

Sarah Hawkes

K.G. Santhya

Population Council

Follow this and additional works at: https://knowledgecommons.popcouncil.org/departments_sbsr-rh

Part of the Demography, Population, and Ecology Commons, Family, Life Course, and Society Commons, Immune System Diseases Commons, International Public Health Commons, and the Women's Health Commons How does access to this work benefit you? Let us know!

\section{Recommended Citation}

Hawkes, Sarah and K.G. Santhya. 2001. "Diverse realities: Understanding sexually transmitted infections and HIV in India," South \& East Asia Regional Working Paper no. 15. New Delhi: Population Council. Version of record: http://dx.doi.org/10.1136/sti.78.suppl_1.i31 


\section{Diverse Realities: \\ Understanding Sexually Transmitted Infections and HIV in India}

Sarah Hawkes

K. G. Santhya

Paper presented at the meeting on 'Phase-specific Strategies for the Prevention, Control and Elimination of Sexually Transmitted Diseases'.

Rome, October 3-6, 2000 


\section{Population Council \\ Regional Office for South and East Asia Ground Floor, Zone 5A, India Habitat Centre Lodi Road, New Delhi 110 003, India}

Population Council, a nonprofit, nongovernmental research organisation established in 1952, seeks to improve the wellbeing and reproductive health of current and future generations around the world and to help achieve a humane, equitable, and sustainable balance between people and resources.

The Council analyses population issues and trends; conducts research in the reproductive sciences; develops new contraceptives; works with public and private agencies to improve the quality and outreach of family planning and reproductive health services; helps governments design and implement effective population policies; communicates the results of research in the population field to diverse audiences; and helps strengthen professional resources in developing countries through collaborative research and programmes, technical exchange, awards, and fellowships.

This issue of the South \& East Asia Regional Working Paper Series was produced by the Regional Office for South \& East Asia, New Delhi, India

Copyright@2001 Population Council

Design and Production: Spectra VisualWord 


\section{Contents}

List of tables and figures $\quad 5$

$\begin{array}{lr}\text { List of acronyms } & 6\end{array}$

$\begin{array}{ll}\text { Acknowledgements } & 7\end{array}$

$\begin{array}{lr}\text { Abstract } & 7\end{array}$

$\begin{array}{lr}\text { Caveat } & 7\end{array}$

1. Introduction $\quad 9$

$\begin{array}{lr}1.1 \text { Demographic profile } & 10\end{array}$

$\begin{array}{lr}1.2 \text { Economic and social profile } & 10\end{array}$

2. Epidemiology of STIs in India $\quad 15$

2.1 Bacterial and protozoal STIs in men $\quad 16$

2.2 Bacterial and protozoal STIs in women $\quad 18$

2.3 Viral STIs (except HIV) in men and women $\quad 21$

$2.4 \mathrm{HIV}$ in India $\quad 22$

2.5 Summary of epidemiological data 25

3. Risk Factors for STI/HIV Transmission in India 27

$\begin{array}{ll}3.1 \text { Nature of sexual networks } & 27\end{array}$

$\begin{array}{lr}3.2 \text { Commercial sex } & 28\end{array}$

3.3 Non-commercial sex, non-marital sex $\quad 29$

3.4 Male to male sexual activity in India $\quad 31$ 
4. Responses to Risk and to Infection 33

4.1 Primary prevention of STIs - barrier methods 33

4.2 Reported morbidity, health care seeking, compliance with treatment, and partner $\quad 34$ communication

5. The Health System in India

5.1 Basic public health organisation and infrastructure $\quad 39$

5.2 Private sector in India $\quad 42$

5.3 The NGO sector $\quad 43$

6. STD Prevention and HIV Control Programmes in India 45

6.1 Surveillance activities $\quad 45$

6.2 STD case management $\quad 47$

6.2.i The effectiveness of care (including costs) $\quad 47$

$\begin{array}{ll}\text { 6.2.ii The quality of care } & 48\end{array}$

6.2.iii Partner notification $\quad 49$

6.3 Other public health measures for STI control 49

6.4 STI prevention and care outside the public sector $\quad 50$

6.5 Voluntary HIV counselling and testing 51

6.6 Care for people living with HIV/AIDS $\quad 52$

7. Expenditure in Health Programmes

7.1 Expenditure in one state $\quad 55$

7.2 Expenditure and allocation for nationwide STD control programmes 56

8. Conclusion $\quad 59$

Epidemiological evidence $\quad 59$

$\begin{array}{lr}\text { Evidence for risk and protective behaviour } & 60\end{array}$

$\begin{array}{lr}\text { Effectiveness of care } & 60\end{array}$

$\begin{array}{ll}\text { Structure of the health service } & 60\end{array}$

$\begin{array}{ll}\text { A vulnerable population } & 61\end{array}$

9. References 


\section{List of Tables}

TABLE 1: $\quad$ Published STI Rates among Men in India

TABLE 2: $\quad$ Published STI Rates among Women in India

TABLE 3: $\quad$ Structure of Public Health Care Services in Rural Areas, and Recommended Essential RTI Services

TABLE 4: $\quad$ Financial Allocation for Components of AIDS Control Programme and Actual Expenditure during the 1990s

FIGURE 1: $\quad$ HIV Prevalence among Antenatal Women in India, 1998 


\section{List of Acronyms}

\begin{tabular}{|c|c|}
\hline AIDS & Acquired Immune Deficiency Syndrome \\
\hline ANC & Antenatal Clinic \\
\hline ANM & Auxiliary Nurse Midwife \\
\hline BSS & Behavioural Surveillance Survey \\
\hline $\mathrm{CT}$ & Chlamydia trachomatis \\
\hline DALY & Disability Adjusted Life Year \\
\hline $\mathrm{GC}$ & Neisseria gonorrhoeae \\
\hline GDP & Gross Domestic Product \\
\hline GNP & Gross National Product \\
\hline $\mathrm{HbsAg}$ & Hepatitis B Surface Antigen \\
\hline HIV & Human Immunodeficiency Virus \\
\hline HPV & Human Papilloma Virus \\
\hline HSV & Herpes Simplex Virus \\
\hline IDU & Injection Drug User \\
\hline IEC & Information, Education, and Communication \\
\hline $\mathrm{INP}+$ & Indian Network of [HIV] Positive People \\
\hline LHV & Lady Health Visitor \\
\hline MPW & Multi Purpose Worker \\
\hline MSM & Men having Sex with Men \\
\hline NACO & National AIDS Control Organisation \\
\hline NFHS & National Family Health Survey \\
\hline $\mathrm{NGO}$ & Non-Governmental Organisation \\
\hline OTC & Over The Counter \\
\hline PHC & Primary Health Centre \\
\hline PID & Pelvic Inflammatory Disease \\
\hline $\mathrm{RCH}$ & Reproductive and Child Health \\
\hline RH & Reproductive Health \\
\hline RPR & Rapid Plasma Reagin \\
\hline RTI & Reproductive Tract Infection \\
\hline STD & Sexually Transmitted Disease \\
\hline STI & Sexually Transmitted Infection \\
\hline SW & Sex Worker \\
\hline TPHA & Treponema Pallidum Haemagglutination Assay \\
\hline TRIPS & Trade-Related Aspects of Intellectual Property Rights \\
\hline UNAIDS & Joint United Nations Programme on HIV/AIDS \\
\hline VDRL & Venereal Disease Regional Laboratory Test \\
\hline WHO & World Health Organization \\
\hline WTO & World Trade Organisation \\
\hline
\end{tabular}




\title{
Acknowledgements
}

This Working Paper was made possible through a grant from the MacArthur Foundation to the Population Council. The themes addressed in the Paper are based on suggestions from the Center for Disease Control, Atlanta, USA, for reviews of 'Phase-specific Strategies for the Prevention, Control and Elimination of Sexually Transmitted Diseases' (for a meeting of the same name held in Rome, October 2000).

We are very grateful to Purnima Mane, Mr. S.Ramasundaram and Janneke van de Wijgert for their extremely helpful reviews of draft versions of the paper.

\begin{abstract}
Sexually transmitted infections (STIs), including HIV, currently have high salience on the health care agendas of many countries, including India. Strategies for their control are ideally based on a number of well-recognised principles. These include: assessments of the burden of disease; the availability of interventions at policy and programme levels, to influence behaviour change and technical 'solutions'; and the calculated cost-effectiveness of these interventions. In the case of India, data to inform these principles are often lacking in the case of STI control. In this paper we have reviewed the evidence base for STI control in the Indian context. The paper is split into a number of sections: a review of the socio-demographic and structural level factors which may indicate vulnerability to epidemics of the sexually transmitted infections; a compilation of the available evidence on the prevalence and epidemiology of these infections; individual level risk factors for infection; responses to risk and infection - both at the individual level and within the pluralistic health service; and a detailed review of the STI/HIV control programme in the country. We conclude with a summary of the evidence base and make suggestions for areas where further work is needed to strengthen this base.
\end{abstract}

\section{Caveat}

Information is, happily, in a state of fluidity. Since writing the original draft of this paper, new information and data have been published and shed new light on our understanding of the HIV/ STI epidemics in India. As far as possible we have tried to update the paper, but we recognise that there will always be gaps, and perhaps whole areas of importance that we have failed to address. We would be very grateful for any further relevant information that anyone reading this Working Paper is able to provide us with, and we will try to incorporate it into our next publication. 


\section{Introduction}

India, like much of South and South-East Asia, is currently facing up to the prospect of a worsening HIV epidemic. Whilst much attention globally is focused on the African HIV/AIDS epidemic and the havoc wrought with it, analysts in India and throughout Asia are in the process of forecasting the likely scale and spread of the epidemic in this region. In many cases, however, there exists relatively little published evidence on which to base any 'predictions'. Within this working paper we attempt to draw together as much information as possible on the extent of the epidemic of sexually transmitted infections (STIs), including HIV, in India. We concentrate on India not only because it is the largest country in the South Asia region (and the second most populous country in the world), but also because we believe it contains the potential for a widespread and sustained epidemic.

Given the well-recognised epidemiological synergy between sexually transmitted infections and $\mathrm{HIV}^{1}$, we have outlined as much background information as possible on these infections. In part, this is because more has been known for a longer period of time about these infections in India than about the more recent arriviste, HIV. Whilst not using STI rates as a proxy for HIV, we do believe that understanding the epidemiology, risk factors and spread of these infections in India will help in identifying and defining the sites for more effective interventions against the spread of HIV. As such, we have concentrated upon STIs rather than on reproductive tract infections (RTIs) in general. While noting that the endogenous and iatrogenic infections among women are a significant cause of acute and chronic reproductive morbidity (and mortality in some cases), and the endogenous infections (such as bacterial vaginosis) may prove also to be co-factors in HIV transmission, it is important to bear in mind that they have different risk and predisposing factors compared to the STIs, and they need to be addressed by a different set of measures for prevention and care. 
We start this working paper with a profile of the macro-level and structural factors which may contribute to the vulnerability of the Indian population for a widespread HIV epidemic. Next, we look at the epidemiology of STIs in India, and follow this with a summary of reported information on individual level behavioural risk factors for these infections. We then review the Indian health care system in general, and its response to STIs and HIV in particular. The final section of this working paper summarises all information gathered, and presents conclusions for future programmatic and research agendas.

\subsection{Demographic profile}

In May 2000, India joined China as one of only two countries with a population of more than one billion. Such statistics obscure the fact that India's population growth rate has, in recent years, been falling. From an annual average population growth rate of above $2 \%$ during the period 1961-91, it fell below $2 \%$ in 1996, and is currently growing at $1.6 \%$ per annum (down from 1.8 in 1997). An examination of the structural characteristics of India's population reflects a macro environment conducive to the increased transmission and incidence of STIs. In many societies, it is younger age groups who have higher rates of STIs - perhaps a reflection of increased sexual mixing at an age associated with general experimentation in all aspects of life. India has noted a decline in the proportion of the younger aged population $(<15$ years $)$ and a marginal increase in the proportion of older and elderly people; however, the population remains young with $36 \%$ aged below 15 years ${ }^{2}$.

The size of the urban population has been steadily increasing and the pace of metropolitanisation (the growth of large cities) is accelerating ${ }^{3}$. Nonetheless, India continues to be a predominantly rural country with $74 \%$ of the population living in rural areas. The most recent figure available for population density, recorded in the 2001 census, shows a level of 324 per sq. km. India is one of the few countries with more males than females, with 933 females for 1,000 males according to the 2001 census. Except in the southern state of Kerala (where there were 1058 females per 1000 males in 2001) and the Union Territory of Pondicherry (ratio of 1001 females per 1000 males in 2001), the sex ratio is unfavourable to females ${ }^{4}$.

\subsection{Economic and social profile}

A 1990s World Bank study of 50 low income countries noted that eight structural level variables could explain up to two thirds of the variation in HIV prevalence between countries: income distribution and measures of absolute wealth (GNP per capita) were two of the explanatory 
variables $^{5}$. India is a low-income country, with a GDP per capita of US\$ 465 in $1997^{6}$. The structural adjustment programmes launched in 1991, intended to improve economic performance through market-oriented policies, may have contributed to an increase in the pace of economic growth in recent years. The Indian economy is expected to grow by $5.9 \%$ in $1999-2000^{7}$. However, the extent to which this improved economic performance has led to equity and social justice is disputable. Official estimates (for the year 1993-4) state that $37 \%$ of the rural population and $32 \%$ of the urban population are living below the income poverty line ${ }^{7}$ with an income of less than US\$1 a day, although some put this figure higher at one in two of all Indians living on a dollar a day ${ }^{8}$. Absolute poverty in India is compounded by inequalities in income distribution: during the period $1990-96$, while the poorest $40 \%$ shared $21 \%$ of the total household income, the richest $20 \%$ shared $43 \%$ of household income ${ }^{9}$.

\section{Whilst poverty itself is not a direct 'risk factor' for STIs (including HIV), it may lead to an increased population vulnerability.}

Whilst poverty itself is not a direct 'risk factor' for STIs (including HIV), it may lead to an increased population vulnerability, for example through changes in population mobility (e.g. young rural men migrating to cities without their families in search of work). Moreover, the ability of low income countries to provide widespread effective preventive interventions and services for clinical management is often compromised through an inability to ensure an adequate drug supply and to undertake screening for asymptomatic infections, or through the reduced ability of people in low income countries to access care from qualified practitioners ${ }^{5}$. In this regard, India and the entire South Asia region constitute one of the world's most vulnerable areas for STIs including HIV.

Nonetheless, the economic picture in India, as in much of South Asia, is not totally bleak. Economic liberalisation policies have opened up the Indian market to outside investment, and India now has, for example, one of the strongest computer software industries in the world. The challenge, as shown above, is to encourage economic growth beyond a few highly selected urban areas and develop means for equitable distribution of income and wealth. 
Geographical disparities in the levels of economic development are very profound in India. These have continued to influence migratory patterns from impoverished rural areas to prospective urban destinations. Selective migration of males has been a traditional feature of internal migration, especially when migration has been pursued for economic gain. Most of these migrants are married, and they leave behind their families in the villages and occasionally return to visit them ${ }^{10}$. An increasing volume of internal migration combined with growing urbanisation may have profound implications in terms of the overall incidence of STIs in the country. Available information on the prevalence pattern of STIs in the country already reflects some of these trends. For instance, the highest reported prevalence of STIs during the period 1984-88 was in the states of Maharashtra and Tamil Nadu which were the most urbanised states in the country at the time of the 1981 census $^{11}$.

In addition to the urban-rural divide, there are consistent differences in indicators of socioeconomic development between the north and south of the country, with the southern Indian states repeatedly outperforming the central belt and parts of the north. Kerala, long held up as a model of development policies, has health outcomes comparable to those of many higher-income countries, despite being economically backward. Infant mortality and under-five mortality rates in this southern state are less than one third of those for India as a whole ${ }^{12}$.

Despite various initiatives to achieve universal primary education, India continues to have a very high proportion of people who have not received any education, especially among girls and women. In 1997, half the adult female population was classed as illiterate. Latest figures from the most recent (1998-99) National Family Health Survey (NFHS-2) show that even among the age group 15-19 years (which might have been expected to benefit more from education policies in the recent past), $32 \%$ of girls and $15 \%$ of boys are illiterate ${ }^{13}$. Rural-urban and regional disparities in the level of literacy are significant; again the southern states generally perform much better on these indicators. Literacy rates in Kerala are $86 \%$ for girls/women and $93 \%$ for boys/men whilst comparable figures for Bihar in up $\%$ ral India are $29 \%$ and $57 \%{ }^{12}$. The combined national primary, secondary, and tertiary gross education enrolment ratio for females is $47 \%$, compared to $62 \%$ for males $^{6}$.

Other indicators of gender disparities are equally profound. In the prevailing patriarchal environment, women's status is low. Women's access to schooling (as noted above), paid employment, and appropriate health care is limited. Health outcomes for women show an 
inegalitarian pattern: contrary to the expected longer life expectancy for women in most areas of the world, life expectancy in India is almost equal between men and women ${ }^{14}$ (although a slight improvement in women's life expectancy over men's has been observed from the 1980s onwards). Disability Adjusted Life Years (DALYs) lost per annum are greater for women than men ${ }^{15}$ and the highest level of DALY disparity is in the reproductive age groups (15-44 years) - a reflection perhaps of the high levels of all-cause reproductive morbidity suffered by women.

In brief, various contextual and structural factors prevailing in India, such as a high proportion of younger age groups in the population, the increasing pace of metropolitanisation and other types of internal population mobility, the unbalanced male-female ratio (leading to an excess of men in cities), geographical and economic disparities, and the vast number of illiterate people, are generally favourable to an increased incidence of STIs, including HIV, across the country. Given the prevailing gender disparities in all fields of life, women in India are and will be disproportionately affected by the risk of STI transmission. 


\section{Epidemiology of STIs in India}

As shown in the introduction, India displays a remarkable level of heterogeneity in all aspects, including the recorded epidemiology of STIs and HIV. Such epidemiological diversity is a reflection of the size of the country, of the "phase" of the STI/HIV epidemic in any one place (rising, stable or declining), and, equally, of the highly variable broader contextual factors influencing prevalence and incidence rates and the ability of the health care system to record and respond to these rates.

Reliable data on the incidence and prevalence of sexually transmitted diseases (STDs) and sexually transmitted infections (STIs)* are limited, mainly due to the inadequacy of the existing surveillance system. It is estimated by the National AIDS Control Organisation (NACO) that the annual incidence rate of STIs is around five \% of the adult population, which implies that about 40 million new STI cases are occurring annually in the country ${ }^{16}$. The burden of disease estimates carried out for the World Bank show that in 1990 approximately 5.6 million Disability Adjusted Life Years (DALYs) were lost due to STIs in India, excluding HIV, with the loss being twice as high for females (3.7 million DALYs) compared to males (1.9 million DALYs) ${ }^{17}$.

It is acknowledged by the authors of the above-mentioned World Bank report and others ${ }^{18}$ that the data sources for such estimates are very limited. Indeed, in the case of DALY estimates for India, predictions were made despite the fact that "no studies were identified providing information on the prevalence of chlamydia" and nine studies formed the basis of the gonorrhoea

* In this paper we have distinguished between the terms STDs - which are associated with symptoms and signs of disease; and STIs - which acknowledges that many infections are carried asymptomatically. 
and syphilis estimates ${ }^{17}$. Nonetheless, there are increasing numbers of studies available from India which show the prevalence of selected reproductive tract infections in both populationbased and facility- or convenience-based samples. The results of these studies, many of which were carried out in the 1990s, are explored below.

Before examining the reported epidemiology of STIs in any detail in India, it is critical to bear in mind possible reasons contributing to epidemiological diversity. Most important among these is the recognition that studies cited do not use either comparable sampling methods or even laboratory diagnostic tests. It is well recognised that a lack of standardisation in laboratory criteria can influence the prevalence reported ${ }^{19}$. In the case of syphilis, for example, some studies report all rapid plasma reagin (RPR - a screening test for syphilis) positive cases, whilst others report only those confirmed by Treponema pallidum haemagglutination assay (TPHA - a confirmatory test for syphilis). Diagnosis of other pathogens, such as Chlamydia trachomatis, shows an even wider variation in methods and standards used, and as a consequence, a highly variable reported prevalence. Besides, in many studies the laboratory methods used are either inadequately explained or are not detailed at all. Retaining this critical perspective on the published data is important for both understanding the current reported figures, and for designing future research and control programmes. We report on the epidemiology of bacterial/protozoal STIs and viral STIs separately. Whilst the risk behaviours for these infections may coincide, their epidemiology varies by virtue of the fact that the viral STI rates are taken to represent lifetime exposure, whilst rates for the other pathogens reflect more recent infection (in the case of syphilis we have tried as much as possible to present data on recent/untreated infections separately from data on those people who exhibit either lifetime exposure or untreated infections). In the case of HIV (and all other pathogens) we concentrate on sexual transmission of the virus since this represents the vast majority of cases where the route of transmission is known. In most sections we have presented the data for men and women separately.

\subsection{Bacterial and protozoal STIs in men}

A review of the existing literature (published and 'grey') highlights a remarkable gender disparity - the vast majority of facility-based studies and community-based studies in India have thus far focused on examining STI rates in women. We located only two surveys of STIs among men in communities in India: a population-based survey of STI prevalence in Tamil $\mathrm{Nadu}^{20}$, and a survey of men participating in a rural education project in Maharashtra ${ }^{21}$ (see Figure 1 for the location of all states in India). Whilst this may reflect the perceived burden of disease imbalance, it is also 
Table 1: Published STI Rates Among Men in India

\begin{tabular}{|c|c|c|c|c|c|c|c|c|c|}
\hline \multirow{2}{*}{ Study population } & \multicolumn{9}{|c|}{ Prevalence ranges (\%) } \\
\hline & $\mathrm{GC}$ & $\mathrm{CT}$ & Syphilis & $\begin{array}{l}\text { Chancroid } \\
\text { (clinical } \\
\text { diagnosis) }\end{array}$ & TV & $\begin{array}{c}\text { HSV } \\
\text { (clinical } \\
\text { diagnosis) }\end{array}$ & $\begin{array}{c}\text { HPV } \\
\text { (clinical } \\
\text { diagnosis) }\end{array}$ & HbsAg & HIV \\
\hline $\begin{array}{l}\text { Community-based } \\
\text { or convenience } \\
\text { samples }\end{array}$ & & & & & & & & & \\
\hline $\begin{array}{l}\text { Males aged 15-45 } \\
\text { years }^{20}\end{array}$ & 3.4 & 2.0 & 0.3 & - & - & - & - & 6.0 & 1.4 \\
\hline $\begin{array}{l}\text { Male participants of } \\
\text { a community } \\
\text { education } \\
\text { programme }^{21}\end{array}$ & 1.7 & 15 & - & - & 5.6 & - & - & - & 0.4 \\
\hline $\begin{array}{l}\text { Transport \& } \\
\text { industrial workers }^{17}\end{array}$ & 2.1 & - & $0.8-4.4$ & - & - & - & - & - & - \\
\hline Facility-based & & & & & & & & & \\
\hline STD clinic patients $^{22}$ & 8.5 & 20.0 & 12.6 & 16.1 & - & 3.0 & 4.9 & - & 2.0 \\
\hline $\begin{array}{llllllll}23 & 24 & 25 & 26 & 27 & 28 & 29\end{array}$ & -25.9 & -30.0 & -57.0 & -34.7 & & -14.9 & -14.3 & & -7.4 \\
\hline $\begin{array}{l}\text { STD clinic patients } \\
\text { with genital ulcers }^{30}\end{array}$ & - & - & - & 33.0 & - & - & - & - & - \\
\hline $\begin{array}{l}\text { Patients attending } \\
\text { primary health care }^{17}\end{array}$ & - & - & 3.6 & - & - & - & - & - & - \\
\hline Specific groups & & & & & & & & & \\
\hline $\begin{array}{l}\text { Spouses of females } \\
\text { with candida \& } \\
\text { trichomonas }^{31}\end{array}$ & - & - & - & - & 60.6 & - & - & - & - \\
\hline
\end{tabular}

Notes: $\mathrm{GC}=$ gonorrhoea $; \mathrm{CT}=$ Chlamydia trachomatis $; \mathrm{TV}=$ Trichomonas vaginalis;

$\mathrm{HSV}=$ herpes simplex virus; HPV = human papilloma virus; HbsAg = hepatitis B surface antigen;

$\mathrm{HIV}=$ human immunodeficiency virus 
clear that we know a lot less about STIs in Indian men than in Indian women. Such a data imbalance has the potential to lead to unbalanced programme responses and interventions.

Table 1 summarises published information on STI rates among men in India. In the following section we use the case of syphilis to highlight the problems with reporting 'prevalence' from studies using different sampling methods and variable laboratory methods. In a communitybased study of men in Tamil Nadu, $0.3 \%$ of the respondents were TPHA positive $\mathrm{e}^{20}$ (and the only other survey of men in a community ${ }^{21}$ did not report on syphilis seroprevalence). In contrast, studies among male transport and industrial workers in Jaipur (Rajasthan) reported a prevalence of $4.4 \%{ }^{17}$ (VDRL+ with TPHA confirmation), and in Chennai (Tamil Nadu) $0.8 \%$ of industrial workers, $4.4 \%$ of transport workers, and $3.6 \%$ of male patients attending a primary health centre ${ }^{17}$ were found to have syphilis, but no details of diagnostic criteria are given. Studies among male patients attending STI clinics have reported syphilis prevalence ranging between 13 and 57\% ${ }^{2225}$ ${ }^{2628}$, again with variations in diagnostic criteria: primary syphilis in $12 \%$ and secondary syphilis in 3\% in Allahabad ${ }^{22}$ (Uttar Pradesh, no diagnostic details given); no distinction between primary and secondary syphilis, and no details of laboratory techniques, but a reported prevalence of 12.6 $\%$ in $\operatorname{Rohtak}^{28}$ (Haryana), 29.7\% in Patiala ${ }^{26}$ (Punjab) and 57\% in Mumbai ${ }^{25}$ (Maharashtra).

Such variations in samples and methods complicate any comparisons between studies, and make the description of a single "Indian scenario" highly problematic.

\subsection{Bacterial and protozoal STIs in women}

Whilst there is more information available on the epidemiology of selected STIs among women in India than among men, the data are still relatively patchy and certainly incomplete given the size of the population. The 1980s and 1990s witnessed a large number of studies undertaken to study the community-based prevalence of gynaecological morbidity, especially reproductive tract infections (RTIs) in various parts of India. Many studies relied upon self-reported morbidity and did not validate with laboratory confirmed diagnoses. Nevertheless, these and other studies have contributed enormously to our understanding of the prevailing epidemiology of RTIs, including STIs, in Indian women.

Table 2 details the prevalence ranges for selected STIs in women in both community-based and facility-based surveys. 
Table 2: Published STI Rates Among Women in India

\begin{tabular}{|c|c|c|c|c|c|c|c|c|c|}
\hline \multirow[t]{2}{*}{ Study population } & \multicolumn{9}{|c|}{ Prevalence ranges (\%) } \\
\hline & $\mathrm{GC}$ & CT & Syphilis & TV & $\begin{array}{c}\text { HSV } \\
\text { (clinical } \\
\text { diagnosis) }\end{array}$ & $\begin{array}{c}\text { HPV } \\
\text { (clinical } \\
\text { diagnosis) }\end{array}$ & $\begin{array}{l}\text { Cervical } \\
\text { dysplasia }\end{array}$ & HbsAg & HIV \\
\hline \multicolumn{10}{|l|}{ Community-based } \\
\hline Ever/currently married & 0.0 & 0.5 & 0.2 & 4.3 & - & 11.8 & $3.8 \%$ Grade & - & - \\
\hline women $^{32} 33 \quad 34353637$ & -4.2 & -28.7 & -8.8 & -27.4 & & & III dysplsia & & \\
\hline $\begin{array}{l}\text { Unmarried \& married } \\
\text { women }^{2038} 39\end{array}$ & $\begin{array}{r}0.3 \\
-3.9\end{array}$ & 5.2 & $\begin{array}{r}0.2 \\
-10.5\end{array}$ & $\begin{array}{r}0.8 \\
-14.0\end{array}$ & - & - & - & 4.8 & 2.0 \\
\hline \multicolumn{10}{|l|}{$\begin{array}{l}\text { Facility-based and } \\
\text { convenience samples }\end{array}$} \\
\hline STD $_{\text {clinic patients }} 2225$ & 1.3 & - & 29.3 & - & 4.0 & 6.7 & - & - & 1.2 \\
\hline 26282940 & -10.4 & & -43.3 & & -15.4 & -15.6 & & & -13.6 \\
\hline Sex Workers 404142 & $\begin{array}{r}4.9 \\
-16.5\end{array}$ & - & $\begin{array}{r}30.0 \\
-63.0\end{array}$ & - & - & 0.5 & - & - & 49.9 \\
\hline Gynaecological OPD & 1.0 & 0.2 & 4.4 & 0.4 & 0.3 & 0.6 & $9.2 \%$ severe & - & 0.0 \\
\hline $\begin{array}{l}\text { patients } 43 \quad 44 \quad 45 \quad 46 \quad 4748 \\
49 \quad 5051 \quad 52 \quad 53 \quad 54\end{array}$ & -5.5 & -31.3 & -5.6 & -26.0 & -25.0 & -42.4 & $\begin{array}{r}\text { dyskaryosis } \\
5.4 \% \text { invasive } \\
\text { carcinoma }\end{array}$ & & \\
\hline $\begin{array}{l}\text { Antenatal patients } \\
55565758\end{array}$ & - & 2.3 & $\begin{array}{r}1.0 \\
-6.2\end{array}$ & 17.8 & - & - & - & - & $\begin{array}{r}0.1 \\
-1.2\end{array}$ \\
\hline Gynaecological & 0.0 & 2.6 & 2.2 & 1.6 & - & - & - & - & - \\
\hline $\begin{array}{l}\text { patients with'vaginitis, } \\
\text { complaints } 596061\end{array}$ & -2.6 & -12.2 & & -17.6 & & & & & \\
\hline $\begin{array}{l}\text { Gynaecological } \\
\text { patients with } \\
\text { 'cervical erosion' }{ }^{62}{ }^{63}\end{array}$ & - & 3.0 & - & - & - & - & $\begin{array}{r}1.6 \% \text { moderate } \\
\text { dysplasia } 1.3 \% \\
\text { severe dysplasia } \\
1.8 \% \text { malignant }\end{array}$ & - & - \\
\hline $\begin{array}{l}\text { Infertility and PID } \\
\text { patients } 64 \quad 656667\end{array}$ & $\begin{array}{r}0.1 \\
-11.0\end{array}$ & $\begin{array}{r}0.5 \\
-24.2\end{array}$ & 0.5 & 0.5 & - & - & - & - & - \\
\hline Acceptors of tubal & 0.1 & 0.0 & 0.5 & 0.9 & - & - & - & - & - \\
\hline ligation 6768 & -2.2 & -0.2 & -7.0 & & & & & & \\
\hline
\end{tabular}

Notes: $\mathrm{GC}=$ gonorrhoea $; \mathrm{CT}=$ Chlamydia trachomatis; $\mathrm{TV}=$ Trichomonas vaginalis $; \mathrm{HSV}=$ herpes simplex virus; $\mathrm{HPV}=$ human papilloma virus; HbsAg = hepatitis B surface antigen; HIV = human immunodeficiency virus 
As with the studies conducted amongst men, there is a wide variation in sampling and laboratory methods used in the reported studies among women. For example, most information on the prevalence of chlamydial infection comes from case-control studies conducted among specific (and probably higher risk) sub-populations such as women with pelvic inflammatory disease (PID), infertility, repeated abortions, or poor obstetric history. Evidence of chlamydial infection (through serological diagnosis for the presence of chlamydial antibodies) ranging between 0.5 and $24 \%$ has been detected in women with PID and infertility ${ }^{65667}$. Other studies have relied upon the more usual diagnostic criteria of detection of chlamydia antigen, but a wide variety of laboratory methods have often been used, sometimes within the same study. Moreover, some researchers have used several screening techniques and reported positivity with any method (i.e. no 'gold standard' confirmation, all screening tests are counted as positive).

India displays a remarkable level of heterogeneity in all aspects, including the recorded epidemiology of STIs and HIV which is a reflection of the size of the country, of the "phase" of the STI/HIV epidemic in any one place and, equally, of the highly variable broader contextual factors influencing prevalence and incidence rates and the ability of the health care system to record and respond to these rates.

There are wide variations in both the reported prevalence of syphilis and diagnostic criteria used. In the general female population (as found in community-based studies) RPR or Venereal Disease Reference Laboratory (VDRL - a screening test for syphilis) positive cases (no TPHA confirmation) range between 0.2 and $10.5 \% 333436$. One study reported results with TPHA confirmation of VDRL positive cases: $4.2 \%$ seropositivity among 332 women in a Delhi slum ${ }^{32}$. Another community based study, this time among rural women in Tamil Nadu, reported TPHA positivity only in $1.5 \%$ of 451 women tested (a further $0.2 \%, 1$ woman, was found to have current syphilis infection, diagnosed by RPR positive serum $)^{35}$. The reported prevalence of syphilis among gynaecology patients again varies according to diagnostic criteria in use: in Allahabad, $2.8 \%$ of 500 gynaecology patients were reported as having syphilis (no further details given) ${ }^{43}$, whilst in Delhi $5.6 \%$ of 144 women were found to be TPHA positive ${ }^{47}$. Another Delhi-based study among 
women in a family-planning clinic found $2.2 \%$ of 319 women were VDRL positive ${ }^{59}$. Studies among antenatal populations have reported seropositivity rates ranging between 1 and $6 \%$, again varying according to diagnostic methods reported. WHO data report $1 \%$ of 9,380 ANC clinic attendees to be VDRL positive in Delhi ${ }^{17}$, whilst $5 \%$ of 10,181 antenatal clinic (ANC) women in Mumbai $^{56}$ and $6.2 \%$ of 250 pregnant women in Allahabad ${ }^{43}$ are reported as having syphilis (no further details given). Reports covering the period 1968-88 present syphilis rates (as defined by VDRL positivity) ranging from 7-23\% among pregnant women in different locations in the country ${ }^{69}$.

Sex workers and women attending STD clinics have been found to have even higher rates of syphilis. For example, among female attendees at STD clinics, between 29 and $43 \%$ have been diagnosed with syphilitic infection: primary syphilis in $4 \%$ and secondary syphilis in $40 \%$, but with no details of laboratory methods ${ }^{22}$ in Allahabad (Uttar Pradesh); $29.7 \%$ in Mumbai ${ }^{25}$ (Maharastra) and 29.3\% in Patiala ${ }^{26}$ (Punjab) (no laboratory or diagnostic details given). Similarly, studies among sex workers (SWs) have found a higher prevalence of syphilis. Among 360 brothelbased SWs surveyed in Kolkata (formerly Calcutta), 58.8\% were reactive by VDRL and $63 \%$ were TPHA positive ${ }^{41}$. A survey of 200 SWs attending a general health clinic in Pune (Maharastra) found $37 \%$ diagnosed with syphilis (no further details given) ${ }^{42}$.

Although variations in sample size and diagnostic procedures account, to some extent, for the differences in reported prevalence, the high prevalence of syphilis among women in some parts of the country is in little doubt. Despite this, prevention of mother-to-child transmission of syphilis (through antenatal screening of all pregnant women) is only patchily implemented throughout the country.

\subsection{Viral STIs (except HIV) in men and women}

Aside from HIV, data on other viral STIs, apart from hepatitis B, are lacking in India. The major route of hepatitis B transmission is believed to be mother-to-child or during childhood, although there is also evidence of the role that non-sterile injection practices may play in transmitting the virus in adult populations 707172 . Recent studies have documented the Indian population as having an intermediate hepatitis B prevalence ${ }^{73}$ (2-7\% prevalence of carriage of hepatitis B surface antigen in the general population), and researchers have recommended universal immunization of neonates as the appropriate strategy for control ${ }^{74}$. The inclusion of hepatitis $\mathrm{B}$ into national immunization programmes has been a WHO-recommended policy since $19922^{75}$, and has been 
shown to be a highly cost-effective strategy in India ${ }^{76}$. Despite such evidence, the country is beginning a vaccination strategy in 15 pilot districts only this coming fiscal year (WHO country office, Delhi, personal communication).

The prevalence of genital herpes in general male and female population in India has not been explored in any of the community-based studies, and there are no community-based seroepidemiological studies on the prevalence of antibodies to HSV-2, although some are planned. Nonetheless, a small number of studies have documented that clinical evidence of infection is not uncommon among men and women in STD clinics. Studies in such settings among men have observed that between 3-15\% were diagnosed clinically as suffering from genital herpes ${ }^{22} 252628$. Prevalence rates of 0.3 to $25 \%$ for antibodies to herpes simples 2 virus (HSV-2) have been found among female patients attending gynaecology and obstetrics out-patient departments ${ }^{47} 4850$ and rates of 4 to $18 \%$ have been found among female patients attending STD $\operatorname{clinics}^{222526}$.

An estimated 90,000 new cervical cancer cases arise annually among Indian women. Despite the fact that this is one of the commonest cancers among all women, little data exist either on the prevalence of different types of cervical dysplasia among women, or on the number of women (and men) infected with human papilloma virus (HPV). Only one community-based study among women in a Delhi slum has reported on the prevalence of HPV infection: 12 and 3.3\% of 152 women had clinical evidence of HPV16 and HPV18 infection (the two papilloma sub-types linked to an increased risk of developing cervical cancer) respectively ${ }^{32}$. Rates of HPV infection diagnosed among both male and female STD patients have been found to be similar and in the range of 5$16 \% 222526$. Clinical HPV infection (which is not necessarily caused by the cancer-associated HPV sub-types) was reported in $0.6 \%$ of a large sample $(\mathrm{N}=69595)$ and $7-42 \%$ of smaller samples of gynaecological patients ${ }^{45} 4754$. Prevalence of cervical dysplasia is similarly little understood: only one study reports on cervical dysplasia in women in a community $(28 / 734 ; 3.8 \% \text { of rural women living in } 20 \text { villages close to a tertiary care facility })^{37}$. Data from other studies are presented in Table 2 - note the differing classification systems used in each study.

\subsection{HIV in India}

The first HIV-positive person was identified in India in 1986, and there has since been a rapid spread of the epidemic in different parts of the country. Accurately estimating the number of HIV positive people in the country is, however, difficult - in part due to the wide national variation in 
contextual factors which may put people at risk (e.g. rates of partner change, urban rural divide, STI rates, prevalence of injecting drug use). However, the National AIDS Control Organisation carried out a consultative modelling exercise late in 1999 to review the figures for the year 1998. Using the HIV sentinel surveillance data as a basis for modelling estimates, they calculated that in 1998 approximately 2.7 million people were infected (range: $2.3-3.5$ million), and that the geographical distribution of these people was as follows: 1.36 million urban males, 0.5 million rural males, 0.86 million urban females and 0.2 million rural females ${ }^{77}$. As of June 2000, there have been a total of 12,389 people diagnosed with AIDS and 98,451 HIV positive people identified through HIV sero-surveillance ${ }^{77}$. Using these figures, it is currently estimated that there are approximately 3.7 million HIV positive persons in India, one of the highest numbers in any country globally. Most of these infections have been acquired through sexual transmission (80.8\%), with a smaller number (5.1\%) found in injecting drug users, people who have received infected blood (5.5\%), and a relatively low number of cases infected through mother to child transmission $(0.8 \%)^{78}$.

India, like many countries, does not have a single HIV epidemic, but has multiple epidemics in different geographical settings and among different people with different types of risk.

India, like many countries, does not have a single HIV epidemic, but has multiple epidemics in different geographical settings and among different people with different types of risk. Initial cases were reported among female sex workers in the cities of Mumbai and Chennai, and among injecting drug users in the north-east of the country (especially in the state of Manipur ${ }^{79}$ ). Since then, however, there has been a diffusion of the epidemic away from recognised 'risk groups', and into the so-called 'general population'.

In 1998, the estimated male:female ratio of HIV infection in India was approximately 1.8:177. Studies show that the number of cases in women infected through heterosexual transmission within marriage is increasing. A seroprevalence of $13-24 \%$ HIV has been reported among female STD clinic patients who did not report themselves to be selling sex 40808182 . In addition, a number of small-scale studies have reported that anywhere from 6 to $85 \%$ of wives of HIV- 


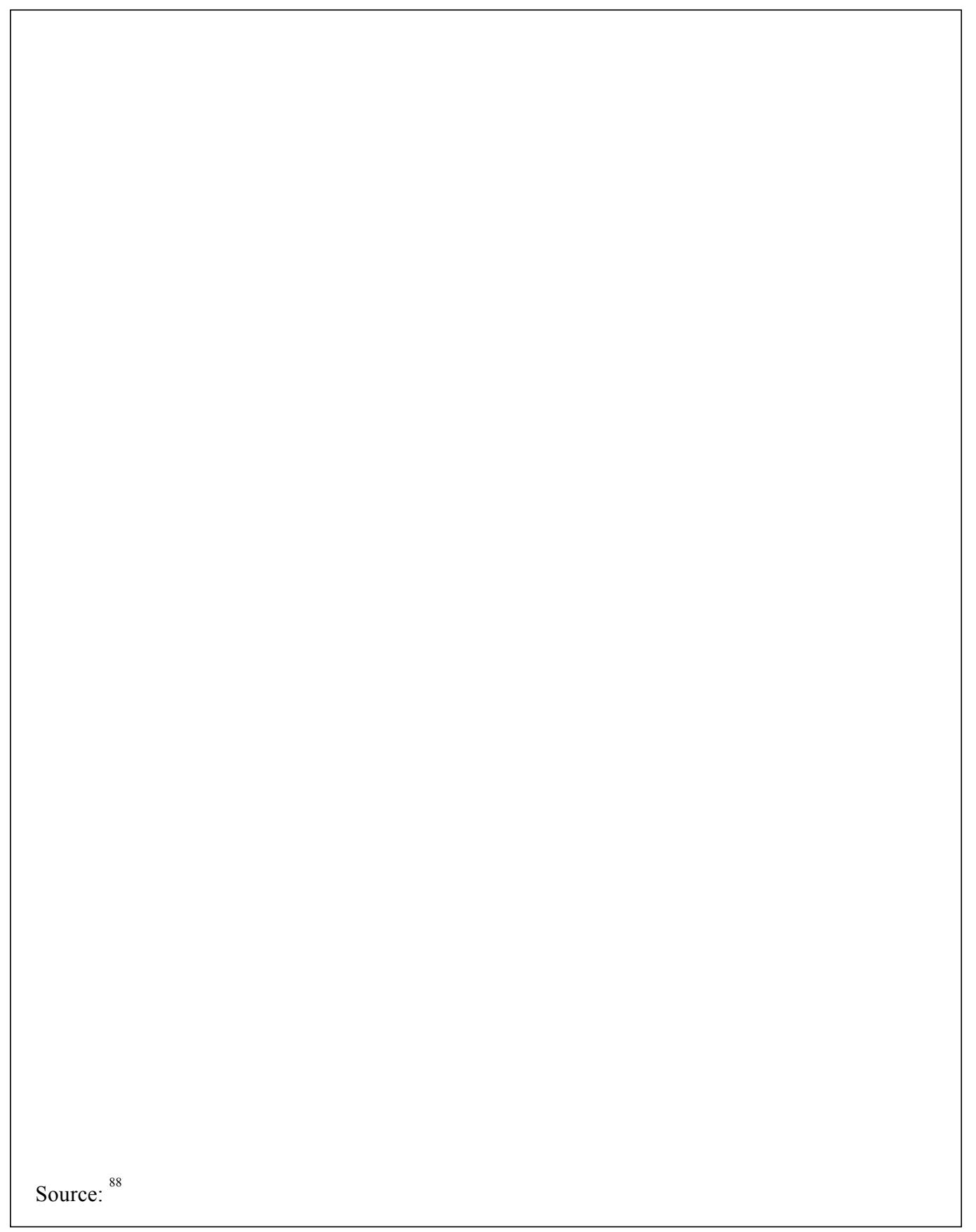


infected intravenous drug users and STI clinic patients were HIV positive ${ }^{83} 8485$. Studies which have examined the prevalence of HIV infection in married women have found that husbands' reported behaviour was the major risk factor for many women 40818687 .

The seropositivity rate among pregnant women in selected sentinel sites ranges between zero and over $2 \%$ (in the states of Maharashtra and Karnataka), and as high as $6 \%$ in some areas of slums of the city of Mumbai ${ }^{16}$. See Figure 1 for an overview of HIV rates among antenatal women - data collected during sentinel surveillance.

\subsection{Summary of epidemiological data}

The HIV and STI data in India highlight the huge variation in reported and recorded prevalence in the country. In the absence of a fully functioning STI surveillance system, predictions and estimates are made on the basis of ad-hoc surveys, often among facility-based or convenience samples. There are few systems for passive surveillance in operation, and even fewer longer-term surveys in existence which might be able to show trends with time. Given this, it is impossible to describe the 'Indian scenario' per se, instead it is only feasible to report the results from community-based and other studies of STI/RTI prevalence, and the data from HIV sentinel surveillance.

As mentioned in the introduction to this section, a critical review of many of the studies reported here reveals highly variable methods in use, especially in relation to laboratory diagnosis. Nonetheless, there are a number of summary points which can be made in relation to the data presented above:

- Data on STI prevalence in men are lacking, especially men in the 'general population';

- Rates of all STIs are generally higher in urban areas than in rural areas;

- The epidemic of HIV is spreading rapidly in India, and is moving beyond recognised 'risk groups' into the wider population in some areas; and

- Interpretation of data from India is complicated by the wide variety of methods for laboratory diagnosis. The need for standardisation of laboratory methods is particularly crucial in any future studies. 


\section{Risk Factors for STI/HIV Transmission in India}

India, like other countries, has a wide variety of individual, community-level, and structural factors which place some people at higher risk of STI transmission. In the introduction we outlined the broader contextual factors which contribute to the sustained (and increasing) prevalence of these infections. In the following sections, the nature of individual-level reported risk has been highlighted. In all studies reported below, however, it is important to be mindful of similar caveats as outlined with the studies of STI prevalence. For example, the definition of "sex" is not clearly articulated in many studies: is it confined only to penetrative vaginal sex, or are other types of sexual experience being recorded? Similarly, definitions of types of sexual partnership are often not well defined within study reports: what and who constitutes a 'casual' partnership/partner, and how is 'commercial sex' defined? Such a lack of methodological information makes the results of many studies difficult to interpret and to compare with one another.

\subsection{Nature of sexual networks}

Although India produced a detailed treatise on sex and love in the third or fourth century of the Christian era, namely Vatsyayana's Kama Sutra, in modern India sexual behaviour has not been discussed openly or researched seriously until recently. The HIV/AIDS epidemic has stimulated a proliferation of research in this area in India. Previously unexplored topics have now entered the domain of public discourse, with media articles now regularly featuring HIV/AIDS and sexual behaviour as their subjects.

Recent studies have provided valuable insights into the nature of sexual behaviour in selected populations in India. However, to date, no studies on sexual networking have been published. Some studies of this type are currently underway in a small number of sites, but in this paper we are restricted to recording the reported level of different types of sexual behaviour. In the subsections below, sexual behaviour patterns within commercial and non-commercial sex are discussed. 


\subsection{Commercial sex}

Prostitution, or sex work, has a very long history in India; the topic was discussed in texts written as far back as the third century B.C. ${ }^{89}$. The number of sex workers (SWs) in India is hard to estimate. However, some non-governmental organisations (NGOs) working with SWs have provided 'guesstimates' for the major cities: between 100,000 and 150,000 female SWs and 2000 male transvestites or eunuchs engaged in male to male sex (MSM) activities in Mumbai; 100,000 SWs in Kolkata; 40,000 in Delhi; 40,000 in Pune (Maharastra); 13,000 in Nagpur (Maharastra); 7,000 SWs in Ahmedabad (Gujarat); and 6,000 SWs in Chennai (Tamil Nadu) ${ }^{89} 90$.

Female SWs can broadly be categorised into four groups - brothel-based; home-based and part-time; street-based; and call girls ${ }^{91}$. Brothel-based SWs constitute the major proportion of prostitutes in the majority of the cities in India. However, there are many cities where there are no established brothels. Brothels vary from highly restrictive arrangements with no freedom of mobility for the women, to a more contractual agreement where women present themselves at the time required by the brothel owner. Normally, pimps or brokers bring customers to brothels. Brothel owners in most cases control the earnings of women working there.

Home-based SWs function independently or through known brokers and networks. The style of operations and the socio-economic status of the home-based SWs vary across cities. Parttime workers are those who are primarily engaged in other occupations, which may provide access to clients. There are also women who sell sex according to seasonal economic need. Streetbased workers come mostly from the lowest socio-economic stratum of society. They seek customers independently. They are the least protected of all SWs and are highly mobile. There are 'day workers', 'night workers', and those working along the highways to serve truck drivers. Call girls work clandestinely through trusted agents or independently and cater to middle and upper class customers - a hidden lifestyle which may make them less easily amenable to prevention methods and messages ${ }^{91}$.

The male clients of SWs are a heterogeneous mixture representing all socio-economic strata of Indian society. The various types of SWs referred to above will each have their different 'catchment' groups of clients. A few studies that have examined the number of clients served by SWs reported that they see, on average, 3 clients a day ${ }^{92} 93$. However, a study in Surat (Gujarat) reported that SWs in this city saw, on average, 10-12 clients per day ${ }^{91}$. 
There are few reports from population-based surveys on the numbers of men who have paid for sex. A study in Orissa found that $15 \%$ of men (urban and rural) reported payment for sex at some point in their lifetime, and other studies have found between 8 and $29 \%$ of men have paid for $\operatorname{sex}^{95}$. One common feature observed in all the studies is that men often go to sex workers in groups $^{96}$.

\subsection{Non-commercial sex, non-marital sex}

The prevailing family system in India is based on monogamous marital sex - and is especially enforced for women. Premarital chastity and marital fidelity are still valued, again, predominantly for women. However, a number of small-scale studies, despite limitations in their design and methodologies, have observed a more permissive attitude towards sexual pleasure and comparatively high (at least, higher than culturally perceived or expected) levels of premarital and extramarital sexual activity among men and women in India.

A number of studies which have explored sexual behaviour among predominantly unmarried school and college students, mostly in urban centres, have reported sexual activity among 8-39\% of male students and among 1-20\% of female students ${ }^{97} 9899100101102103104105$. Studies in the general population, in both rural and urban areas, have reported premarital sexual activity among 7-48\% of male respondents and 3-10\% of female respondents 353695106107108109110111 . A study in tribal villages in Maharashtra reported higher levels of sexual experience among unmarried girls, with nearly half of all unmarried girls found to be sexually experienced ${ }^{38}$ as diagnosed on gynaecological examination. Again, the problem with making any generalisation from the results of these multiple studies is that different methods have been used and diverse definitions of sexual activity are common. For example, is it possible to compare self-reported sexual activity with 'sexually experienced' diagnoses made on clinical examination? Often, the exact methods and definitions are not outlined in study methods, thus making comparisons even more tenuous.

Small-scale studies among groups such as STI clinic patients and truck drivers have reported a higher level (81-98\%) of premarital sexual experience ${ }^{112}{ }^{113}$, compared to rates in the general population. Reports of STI clinic patients have shown that between 7 and $22 \%$ of male patients (the majority of them were unmarried) and between 12 and $44 \%$ of female patients (the majority

* Premarital sexual experience was defined when the hymen was found to be torn and when it was easy to insert two fingers into the vagina on pelvic examination. 
of them were married) were teenagers ${ }^{2628114}$. These studies suggest that sexual activity at younger ages outside a marital union is not as uncommon as generally believed.

However, others have argued that premarital sex is not the norm, and that for the majority of people, their first sexual experience occurs within marriage ${ }^{96}$. A recent large population-based survey in Orissa among over 2000 urban and rural men found that only $25 \%$ had sex before marriage, and the overall mean age at first sex was 23 years ${ }^{95}$. Even studies among college boys (where social constraints may be relaxed) have found that less than one third report sex before marriage ${ }^{115}$.

Reports (often from qualitative studies) of premarital sexual contacts of men have found a wide variety of partners: SWs; friends; relatives; and future spouses 35369599100106109110116 . Among girls, reported premarital sexual contact is mainly with future spouses, friends and relatives ${ }^{36101}$.

The few studies which have looked at the extent of extramarital sexual activity (i.e. nonspousal sex reported by married people) in the 'general population' have found relatively low reported levels. These studies have reported extramarital sexual experience among $2-6 \%$ of women and $4-12 \%$ of men 353695100109110112 . It is hard to say whether these figures accurately reflect reality or if they are an underestimate due to fear of disclosure. Many of the studies of sexual behaviour suggest that men often pay for extramarital sex. Extramarital sexual intercourse with friends and relatives has also been reported, but to a lesser extent.

A review of reports of STD clinic patients suggests that the extent of extramarital sexual activity is probably higher in this group. Between $30-60 \%$ of all male patients diagnosed with STDs were married and 50-98\% of them reported extramarital relationships 262830114117118 . Similar reports from female STD clinic patients found that between one in five and one in two women mentioned husbands as the source of their $\mathrm{STD}^{2628}$, suggesting that many women may have been infected through other partnerships.

\subsection{Male to male sexual activity in India}

Male to male sexual activity has been described in India since the time of the Kama Sutra. However, open discussion of men having sex with men (MSM) is not well tolerated in a society which continues to place extremely high values on the family and lineage. Recent research has concentrated on describing the practices, lifestyles and cultures of MSM in India, but not on 
hypothesising the extent of the practices among men. In part this may be a result of the often hidden nature of male to male sex in India. Researchers in two recent studies found that most men reporting MSM were married, and they met their sex partners in covert and discreet surroundings ${ }^{119}{ }^{120}$. Most of the interviewees first had sex with another man/boy at a relatively young age and most reported non-penetrative sex most commonly. Perhaps because of this, use of condoms was relatively infrequent, ${ }^{96}$ although it has been reported that $15-20 \%$ of older men regularly used condoms ${ }^{119}$.

The possible contribution of male to male sex to the HIV epidemic in India is not recorded as a separate category. Defining this is likely to be a difficult task given the hidden nature of MSM in the country. For example, the fact that most MSM interviewed in studies are married, may lead to their being classified as heterosexual in any survey of HIV prevalence. 


\section{Responses to Risk and to Infection}

\subsection{Primary prevention of STIs - barrier methods}

The use of condoms in marital and non-marital sexual relationships is very limited in India. Method-specific contraceptive targets were only removed from the national agenda in April $1996^{121}$. One result of a target-driven approach has been the predominance of permanent contraceptive methods. The National Family Health Survey (NFHS-2), conducted during 1998-1999, reports that $48.2 \%$ of all married couples were using any (traditional or modern) method of contraception and that among $71 \%$ of these couples, the wife had undergone a tubectomy (i.e. $34.2 \%$ of all married women aged 15-49 years are sterilised $)^{13}$. The same NFHS found that only $3.1 \%$ of married couples were currently using condoms as a method of family planning. The number of married couples who use condoms to prevent transmission of infection is not recorded. However, studies on the acceptability of dual methods of protection are currently planned.

The use, especially the consistent use, of condoms in non-marital sexual liaisons is also reported to be very low. Studies among the 'general' male population who reported non-marital sexual experience found that between $50 \%$ and $88 \%$ never used condoms during such encounters and a very small proportion (4-13\%) reported always using condoms during non-marital sexual liaisons ${ }^{3695103109}$. Studies among groups at perceived or known higher risk (SWs and their clients) have shown that between $4 \%$ and $23 \%$ reported always using condoms ${ }^{40} 122123$.

Besides condom use, other barrier methods for prevention of pregnancy and protection against STIs are not commonly used in India. In part this is due to their non-availability in a system still attempting to expand away from its previous single-method domination. Moreover, 
the client acceptability of other barrier methods is not well understood in the Indian context. Similarly, there are little data on the acceptability of microbicides for HIV prevention - if these become available - although clinical trials of microbicides are currently underway in the country.

\subsection{Reported morbidity, health care seeking, compliance with treatment, and partner communication}

Much information on the prevalence of STI/RTI-associated morbidity in India comes from recent studies, referred to earlier, on self-reported gynaecological morbidities. These studies, found that between $13 \%$ and $57 \%$ of women reported a current abnormal discharge ${ }^{124}$. In many of these studies reported symptoms were equated synonymously with the presence of RTIs (including the endogenous infections) in women. Such a correlation is ambiguous and usually poor, even at the best of times ${ }^{125}$, and the co-ordinators of the studies recognise the need for laboratory-based information in addition to self-reported morbidity ${ }^{124}$.

\section{Only $3.1 \%$ of married couples were currently using condoms as a method of family planning. The use, especially the consistent use, of condoms in non-marital sexual liaisons is also reported to be very low.}

In India, the relationship between these reported symptoms and the presence of a biomedically identifiable infection as their cause, is compounded by the widely prevalent Ayurvedic belief system which equates discharge syndromes (dhatu loss) with loss of bodily power. Studies among both men and women have found a high prevalence of reported "abnormal discharge", but frequently with no biomedically defined cause for these symptoms ${ }^{126}{ }^{127}$. These findings highlight the role of culturally defined illness patterns in health seeking for possible RTI/STI symptoms in India (and possibly in other South Asian countries as well), and stress the importance of understanding the cultural background underlying results from large-scale studies.

Systems of health belief are not, of course, confined to women. Surveys among men in India have highlighted similar patterns of reported morbidity and causality. A large-scale populationbased survey of sexual health problems among over 2000 men in rural and urban Orissa found that the most common concerns among men related to sexual health in general, and psychosexual 
concerns in particular. The most frequently cited symptom was "dhatu phadiba" - involuntary semen loss, believed to be due to excessive heat in the stomach, an improper diet, or sexual causes such as excessive masturbation or prolonged sexual abstinence. This was reported by over a quarter of respondents as their main sexual health problem ${ }^{95}$. This finding has been echoed in other studies which highlight the importance of general sexual health concerns (and specifically, psychosexual problems) in men relative to their concerns about STIs ${ }^{126}$. From a public health perspective, the importance of these findings relates to the cultural meanings and explanations of causality that give rise to them: these will determine the pattern of health care seeking (if any) that a person with symptoms deems to be appropriate.

\section{The most frequently cited symptom was "dhatu phadiba" - involuntary semen loss, believed to be due to excessive heat in the stomach, an improper diet, or sexual causes such as excessive masturbation or prolonged sexual abstinence. This was reported by a quarter of respondents as their main sexual health problem.}

Treatment seeking in India is determined by a number of contributing variables, among these are: perceived seriousness and causality of symptoms; availability of health care; costs (including opportunity costs) of treatment; perceived and actual quality of care (including confidentiality of symptoms); accessibility of different types of care; and belief systems concerning the appropriate provider to consult. There is a strong and prevalent system of indigenous medical care in India and a multitude of different providers in the formal and informal sectors. All of these factors contribute to where, when, and why people seek care.

Indian studies have reported wide variations in treatment seeking behaviour. A few studies have reported that only a small proportion of women seek treatment for gynaecological symptoms ${ }^{34}$ 3538128 . However, a number of studies have reported that $50-78 \%$ of the women with gynaecological symptoms have sought some form of treatment ${ }^{36} 129130131132133$. Some studies have found that women with gynaecological complaints may delay seeking treatment ${ }^{36}{ }^{133}$. For example, symptomatic women in a study in rural Tamil Nadu waited, on average, for a month before 
seeking any treatment ${ }^{36}$. A qualitative study among Gujarati women reported the sequences of treatment seeking for a variety of reproductive health problems including 'white discharge', urogenital problems, menstrual problems, infertility, and uterine prolapse. The study found that women mainly seek treatment from allopathic practitioners (private, qualified or not, and qualified government providers) $)^{131}$.

Much less is known about the health seeking behaviour of men with possible STIs, as very few studies have examined male treatment seeking behaviours. Some of these studies have observed that men also suffer in silence or resort to self-treatment for STIs and other sexual health problems ${ }^{36}$ ${ }^{134}$. A few studies, however, have reported that between one-half and all symptomatic men consulted someone or sought allopathic treatment ${ }^{111}{ }^{135}$.

\section{Indian studies have reported wide variations in treatment seeking behaviour. A few studies have reported that only a small proportion of women seek treatment for gynaecological symptoms. A number of studies have reported that 50-78\% of the women with gynaecological symptoms have sought some form of treatment. Some studies have found that women with gynaecological complaints may delay seeking treatment.}

A review of studies of male STI clinic patients shows that though higher proportions of men than women seek curative care for STIs, the pattern of their treatment seeking is quite inadequate for a complete cure of the infection and a further transmission of infection to sexual partners is likely. For instance, Ganguli and colleagues ${ }^{136}$ reported that only slightly more than one-third of patients completed the recommended treatment regimen and nearly one-third had resorted to self-treatment with antibiotics before seeking treatment from STI clinics.

Women in three studies reported that they often did not inform their husbands about their gynaecological symptoms ${ }^{36} 133137$. Women are often, as noted by Ramasubban ${ }^{138}$, 'too afraid and confused to bring this [symptoms] to the notice of the family ..., both because they are not supposed to have such problems in the first place and also because they are socially deemed to be polluters, 
the originators of sexual problems'. In contrast, Patel ${ }^{139}$ and Oomman ${ }^{132}$ both reported that women discussed their symptoms with their husbands.

A study among married women and men in rural Tamil Nadu reported that only slightly more than one-third (37.3\%) of women with symptoms of possible RTIs, and one-fifth (19.9\%) of the symptomatic male respondents informed their spouses about their illness experience ${ }^{36}$. Both men and women often talked indirectly about their genital illness experience to their spouses, using symbolic expressions and gestures and leaving the 'informed' spouses to guess about their partners' illnesses. 


\section{The Health System in India}

\subsection{Basic public health organisation and infrastructure}

Public health in India has been a stated government priority since independence. Nonetheless, current spending in the broad health sector is only $0.7 \%$ of $\mathrm{GNP}^{140}$, with a per capita health expenditure by central government of approximately $\$ 1$ per annum ${ }^{141}$. Although there has been an attempt in recent years to increase the \%age of spending in social sectors (such as education, health, and social welfare), their overall share of aggregate government expenditure has not increased. The share of central government expenditure on health and family welfare has remained stable at less than $2 \%$ of the total during the last decade. In contrast, the share of expenditure on debt interest payments has increased from $23.9 \%$ in $1991-92$ to $29.9 \%$ in $2000-1$ and the share of defence expenditure out of the overall expenditure has risen from $14.7 \%$ in $1991-2$ to $17.3 \%$ in $2000-1^{142}$.

The emphasis of government policy and priorities in health has shifted in keeping with the wider currents of debate about the meanings of public health and, more specifically primary health care (see, for example, Walsh and Warren ${ }^{143}$ or Rifkin and Walt ${ }^{144}$ ). In recent years, both the public and private social sectors in India have undergone a series of changes as a result of both internal pressures (the demands of the growing middle classes fostering the development of private services, for example), and external forces (the donor-driven structural adjustment policies of the 1990s, for example). The health sector has mirrored the structural changes occurring in Indian society (see Qadeer ${ }^{145}$ for a review of this area).

Financing for the health programme is divided between state-level and central-level expenditures (for example, public health and hospitals are predominantly state-financed, whilst 
primary health care is split between state and centre) ${ }^{146}$. Whilst primary health care services have always been intended to be relatively comprehensive in scope and coverage, the reality of service delivery in India has varied according to the perceived competing demands of national priorities. Thus, for most of the 1970s and 1980s, much of the reproductive health service delivery was directed at achieving family planning targets, and not at preventing or alleviating more general reproductive or other health problems.

\section{Whilst primary health care services have always been intended to be relatively comprehensive in scope and coverage, the reality of service delivery in India has varied according to the perceived competing demands of national priorities.}

However, the government's commitment to policy change following the International Conference on Population and Development in 1994 and the 1995 Beijing Women's Conference has recently resulted in a paradigm shift away from vertical family planning services and towards the provision of comprehensive integrated reproductive health (RH) care at all levels of the health sector ${ }^{147}$. 'Client centred, demand driven, high quality, integrated services' ${ }^{148}$ are the principles guiding service delivery. Public health services are free at the point of delivery, although patients usually have to pay for drugs and diagnostic services.

The shift towards provision of 'comprehensive' reproductive health care has stimulated a great deal of interest in the appropriate type of service delivery at various levels of the health service. In rural areas there are three main tiers within the public sector services: sub-centres are the first point of contact at grass roots level. Primary health centres, which act as referral units for six sub-centres, are maintained by state governments under the Basic Minimum Services Programmes. Community health centres, the next level of care, are established and maintained by the state governments. Finally, district hospitals, located usually in urban or peri-urban settings, constitute the apex health care facility in this pyramidal set-up. A description of the type of personnel and populations served by each of these facilities is shown in Table 3. In addition, Table 3 outlines the proposed essential services for the management of RTIs to be delivered at each level of care (adapted from World Bank ${ }^{149}$ ). 
Table 3: Structure of Public Health Care Services in Rural Areas, and Recommended Essential RTI Services

\begin{tabular}{|c|c|c|c|}
\hline Centre & $\begin{array}{l}\text { Average } \\
\text { population } \\
\text { served }\end{array}$ & $\begin{array}{l}\text { Staffing norms \& } \\
\text { facilities }\end{array}$ & $\begin{array}{l}\text { Recommended Essential } \\
\text { Services for RTI } \\
\text { management }\end{array}$ \\
\hline $\begin{array}{l}\text { Community } \\
\text { level }\end{array}$ & - & - & $\begin{array}{l}\text { - Sexuality and gender information, } \\
\text { education and counselling for high } \\
\text { risk adolescents, general youth, } \\
\text { men and women } \\
\text { - Condom distribution }\end{array}$ \\
\hline Sub-centre & 4595 & $\begin{array}{l}1 \text { male multi-purpose } \\
\text { worker (MPW) and } \\
1 \text { female MPW/ assistant } \\
\text { nurse midwife (ANM) }\end{array}$ & $\begin{array}{l}\text { - As above, plus: } \\
\text { - Syndromic management } \\
\text { - Referral mechanisms } \\
\text { - Partner notification }\end{array}$ \\
\hline $\begin{array}{l}\text { Primary health } \\
\text { centre }\end{array}$ & 27345 & $\begin{array}{l}1 \text { medical officer and } 14 \\
\text { para-medical and other } \\
\text { staff, } 4-6 \text { beds }\end{array}$ & $\begin{array}{l}\text { - As above, plus: } \\
\text { - Routine serology for syphilis } \\
\text { testing in antenatal women }\end{array}$ \\
\hline $\begin{array}{l}\text { First referral } \\
\text { unit/District } \\
\text { level hospital }\end{array}$ & 232000 & $\begin{array}{l}4 \text { specialists, i.e., surgeon, } \\
\text { medicine, gynaecologist, } \\
\text { and paediatrician; } \\
21 \text { paramedical and other } \\
\text { staff; } 30 \text { beds; } 1 \text { operating } \\
\text { theatre; X-ray; labour } \\
\text { room and lab facility }\end{array}$ & $\begin{array}{l}\text { - As above, plus: } \\
\text { - Laboratory diagnosis and } \\
\text { treatment of RTIs including } \\
\text { STIs }\end{array}$ \\
\hline
\end{tabular}

Source 149150

Under the Urban Revamping Scheme introduced in 1983, health posts were established to provide service delivery outreach, primary health care, family welfare and maternal and child health $(\mathrm{MCH})$ services in urban areas. Health posts, along with municipal hospitals, medical schools and specialised hospitals, cater to the health service needs of the urban population. Health care facilities providing Indian Systems of Medicine, such as, Ayurveda, Siddha, and Unani are also part of the public sector health facilities. 
In addition to the large-scale public sector services described above, health care is also provided to lower paid government employees through the Employees State Insurance Scheme. This is a para-statal national social security organisation which runs a full range of medical services and is financed through a mix of employee and employer contributions. The numbers of people covered are large: Delhi (population approximately 12 million) has 2.2 million people insured through this scheme.

\subsection{Private sector in India}

In recent years, the already prolific private sector has expanded in India. 'Private sector' is not a homogeneous term, but encompasses all those providers (formal and informal providers, and the for-profit and not-for-profit sectors) who are not directly financed by the state. In addition to the types of providers seen in many other countries, India has a widespread system of indigenous medical practitioners. As shown above, the majority of clients with symptoms of possible RTIs (including the STIs) seek care outside of the public sector services; in fact NACO estimates that only $5-10 \%$ of patients with STIs present to public sector care ${ }^{16}$. This is true not just for STIs, but for a wide range of curative services, and it is not only the economically wealthy who seek private medical care; the poor choose private providers for a variety of reasons as well.

Despite the size and complexity of the private sector in India, its functions, motivations, and general structure are relatively poorly understood and documented. It is recognised, however, that in allopathic medicine at least, there are integral links between the public and private sectors.

Despite the size and complexity of the private sector in India, its functions, motivations, and general structure are relatively poorly understood and documented. It is recognised, however, that in allopathic medicine at least, there are integral links between the public and private sectors. Both are often staffed by the same practitioners - a survey of 258 physicians in New Delhi found that among those employed in the public sector, $81 \%$ also worked in private practice ${ }^{151}$. Patients attending public sector services may find themselves referred to the private sector for diagnostic services, 'second opinions', or services not offered by providers in their public sector guise (termination of pregnancy is one example of such a practice). 
The private sector is currently largely unregulated, and not subject to safeguards which exist within the public sector (assuring access to services, for example). Most of the services are curative: the private sector is rarely involved in prevention of illness, but one recent exception has been the growth in the 'social' marketing of condoms. Moves are underway to try and implement some degree of control and ensure standardisation of service delivery, but as in many countries, the exact mechanisms for achieving this are not clear, and there is little evidence concerning the effectiveness of any proposed mechanisms. One of the difficulties in achieving regulation within the private sector is the relative stakeholder strength. The allopathic private sector has grown considerably in the recent past, and the ability of the state to exert control over this sector is increasingly questioned. One possible procedure for increased state regulation which is now being discussed is to develop public-private collaboration through, for example, the government subcontracting services from the private sector. However, the ability of the state to be both partner and regulator of the private sector is a dialectic which is still in evolution.

\subsection{The NGO sector}

As is the case with many countries, the not-for-profit NGO sector in India plays an influential and important role in many of the social sectors. In health care, there is a predominance of NGO activity in the delivery of interventions in the field of reproductive health in general, and HIV/ AIDS in particular. The programmes initiated by NGOs tend to have a greater degree of flexibility and more opportunities for innovation than can be provided in the public sector. The NGO scene ranges from small grass-roots organisations working in defined locales to large-scale institutions with multiple sites and target populations. This is further explored in Section 6.4. 


\title{
6. STD Prevention and HIV Control Programmes in India
}

\author{
A National STD Control Programme was initiated in 1946 (prior to the establishment of \\ independent India) which was in operation until 1991. The programme focused on the health \\ seeking behaviour of individuals with STDs and on combating social stigma associated with \\ these infections. With the emergence of the HIV epidemic, the National STD Control Programme \\ was made an integral part of the National AIDS Control Programme in 1992. The major objectives \\ of the current STD Control Programme are to reduce STD cases and thereby control HIV \\ transmission and to prevent short term and long term morbidity and mortality due to STDs. The \\ major strategies for achieving these objectives include ${ }^{16}$ : \\ - development of adequate and effective programme management; \\ - promotion of information, education, and communication (IEC) activities for the \\ prevention and transmission of STD and HIV infection (including condom promotion); \\ - comprehensive case management including diagnosis treatment, individual counselling, \\ partner notification, and screening for other diseases; \\ - increasing access to health care; and \\ - early diagnosis and treatment through case-finding and screening.
}

\subsection{Surveillance activities}

HIV surveillance began in 1985 with screening of blood from 'high risk groups' in two cities. With the objective of identifying the geographical spread of HIV infection and the major transmission modes, surveillance activities were extended in 1986 by establishing 62 surveillance 
centres. Sentinel surveillance was introduced in 1993 in 55 sentinel sites to monitor trends in different parts of the population. An additional 125 sentinel sites were established during 199798. AIDS case surveillance is an important component of the surveillance activities and all medical institutions are required to report suspected AIDS cases, and referral institutions report all identified patients, to the National AIDS Control Organisation.

STD surveillance through syndrome-based information from peripheral health institutions under the primary health care system and aetiological information from STD clinics is due to be introduced, but neither this nor other forms of STI surveillance have yet started.

The first wave of behavioural surveillance surveys (BSS) in India was

launched in Tamil Nadu in 1996 and was followed up with successive surveys to observe trends in high-risk behaviour among selected subpopulation groups such as female sex workers, truck drivers and helpers, male and female factory workers, and students.

Behavioural surveillance has recently been incorporated into HIV surveillance activities and baseline surveys are currently underway in a number of settings. The first wave of behavioural surveillance surveys (BSS) in India was launched in Tamil Nadu in 1996 and was followed up with successive surveys to observe trends in high-risk behaviour among selected subpopulation groups such as female sex workers, truck drivers and helpers, male and female factory workers, and students. Thus far, four survey rounds have been conducted. In each wave, data have been collected on a number of knowledge and behavioural indicators: knowledge of HIV transmission modes and of STD/HIV/AIDS prevention measures; sexual behaviour with non-regular partners; condom use during last sexual encounter with a non-regular partner; prevalence of self-reported vaginal/urethral discharge; STD treatment seeking behaviour; and perception of risk of HIV/ AIDS $^{152}$. Findings from the first three rounds of BSS in Tamil Nadu suggest that knowledge of methods of prevention of STI/HIV has increased among all targeted sub-populations; misconceptions about HIV transmission have reduced for all groups except female sex workers; sexual intercourse with non-regular partners decreased among two of the population groups (trucking staff and male factory workers) and it continues to remain low in female factory workers; 
condom use with non-regular sex partners has gradually increased for all the groups; self-perceived risk of contracting HIV has increased for population groups engaging in 'high-risk sexual behaviour'; and treatment seeking behaviour for symptoms of urethral discharge decreased somewhat in the third round ${ }^{153}$.

Behavioural surveillance surveys on similar lines have been launched in other states: West Bengal (2 rounds), Andhra Pradesh, Gujarat, Kerala, and Orissa (1 round each). The subpopulations targeted for surveillance activities vary among states, but female sex workers and their clients are common surveillance targets. In addition, a nationwide behavioural surveillance survey of trucking staff has been undertaken (Dr. Thomas Philip, Family Health International, personal communication).

\subsection{STD case management}

The main strategy aimed at achieving the objectives outlined above has been to integrate STD services into the existing health care system (public and private), with a special emphasis on integration at the primary health care (PHC) level. As in many countries, this has resulted in the development of case management guidelines and a large scale training programme for health workers. There are 504 specialised public sector STD clinics in the country (usually attached to district or other level hospitals), and these have also been strengthened as part of the overall national STD strategy. Further, the five regional teaching and training centres, which also house the microbiology referral laboratories, have been upgraded.

\section{2.i The effectiveness of care (including costs)}

Syndromic management is recommended by the National AIDS Control Organisation (NACO) for case management at the primary health care level ${ }^{16}$. The effectiveness of syndromic management in women is currently under debate, but it is recognised that effectiveness (including costs per infected person treated) is related to prevalence ${ }^{154}{ }^{155}$. As outlined in the introduction, the prevalence of RTIs (including STIs) varies widely within the country, so reviews of the effectiveness of particular management strategies cannot be extrapolated. Recent reviews of the effectiveness of syndromic management found only one such study from India ${ }^{156}{ }^{157}$. This was carried out in New Delhi among over 300 symptomatic women seeking care in an NGO reproductive health clinic ${ }^{59}$. The STI prevalence in this clinic population was reasonably high with $22 \%$ of women having an STI (chlamydia, trichomonas or syphilis; none with gonorrhoea) diagnosed in the laboratory, including $12 \%$ with Chlamydia trachomatis. As with other studies, the recommended syndromic 
flow charts performed well for the management of vaginal infections, but the STIs were poorly managed with only $5 \%$ of women infected with chlamydia receiving appropriate treatment. Reviews of the effectiveness of care for men could not be located.

The NACO 1998 Country Scenario states that "syndromic management has been favoured in the management of STD cases because of its cost effectiveness", however, we were unable to locate any Indian STI cost-effectiveness data preceding the publication of this document. The global review of the costs of syndromic management ${ }^{158}$, referred to above, calculated (using published Indian market drug prices) that in the Delhi-based evaluation of syndromic management, the per woman drug costs of treating symptomatic women using recommended guidelines were US $\$ 0.61$ per woman (rising to US\$0.78 if the costs of staff time were included as well) ${ }^{157}$. Calculation of the cost of treating women who were actually infected with either gonorrhoea or chlamydia revealed a calculated drug cost of US $\$ 97.65$ per infected woman. For comparison, the per capita health expenditure by the Indian government currently stands at $\$ 1$ per annum ${ }^{141}$.

\section{2.ii The quality of care}

Long ignored as an issue within reproductive health care in India, there is a current programme shift towards incorporating objectives of quality of care within the public sector services. This represents a significant step forwards for the health care system. However, moving beyond rhetoric to actually implementing change has not yet been noticeably achieved in many parts of the country ${ }^{159}$. Whilst there are some detailed case studies available on the quality of services within the broad family planning system (see Koenig and $\mathrm{Khan}^{159}$ ), there are remarkably few studies addressing this issue for STI clients.

The few studies which do exist have found that the quality of STD case management, especially STD counselling for prevention, in STD clinics is inadequate and poor ${ }^{160} 161162$. Observations of STD consultations in Chennai revealed that advice of condom use for prevention of STDs was given during only $30 \%$ of the consultations; instructions on how to use condoms were imparted to $6 \%$ of the clients; and condoms were provided to $1 \%{ }^{160}$.

In the rural study in Tamil Nadu, referred to earlier ${ }^{36}$, it was observed that only $15 \%$ of the symptomatic women who had sought treatment from a health care facility were informed by the providers about the cause of their symptoms or the precautions to be taken to avoid the illness. Slightly more than one-quarter (28.3\%) of the symptomatic men who sought treatment from a 
heath care facility were advised by their doctors about the cause of their symptoms and the precautions which needed to be taken.

\section{2.iii Partner notification}

Partner notification is seen as a cornerstone of effective STI management, but studies in India have shown that this procedure is rarely discussed or initiated by health care providers. For instance, a clinic based study in Chennai ${ }^{160}$, observed that advice on partner notification was given during only $27 \%$ of the consultations. Similarly, a clinic based study in Delhi reported that none of the 100 male and female STD patients were advised about partner notification ${ }^{161}$. In a community-based study in rural Tamil Nadu, it was reported that none of the symptomatic (suggestive of RTIs) women and only $5.7 \%$ of the symptomatic men were advised to have their spouses examined for a possible infection ${ }^{36}$.

Partner notification is rarely discussed or initiated by health care providers. A clinic based study in Chennai observed that advice on partner notification was given during only $27 \%$ of the consultations.

Along with problems on the part of providers in the field of partner notification, there is an added difficulty with some male STD patients falsely identifying themselves as unmarried or giving untraceable addresses ${ }^{138}$. Jeyasingh and colleagues ${ }^{163}$ observed that levels of awareness among male STD patients about the need for partner referral and sexual abstinence were very poor.

\subsection{Other public health measures for STI control}

Aside from strengthening case management, the other pillars of public health interventions for STI control are implemented more patchily throughout the country. There has been a public sector syphilis screening programme for pregnant women since the 1950s. However, this is applied unsystematically, and is further compromised by the fact that nationally only $57 \%$ of women receive antenatal care in the public sector ${ }^{12}$. Even women seeking antenatal care are likely to only receive a limited range of services - less than half have their blood pressure checked, for example ${ }^{12}$. The opportunities for other interventions are also limited - in rural India, only $33.6 \%$ of births 
are attended by a health professional ${ }^{13}$ (doctor, nurse/midwife, or other health professional) and less than a quarter of births are in institutional settings, thus reducing the impact of ophthalmia neonatorum prevention programmes for example.

Cervical cancer screening is another example of a programme that is only in its infancy in India. Annually, approximately 90,000 women develop cervical cancer in India, but the absence of a screening programme means that many of these women do not present for care until the cancer is at an advanced stage (communication from Institute of Cytology and Preventive Oncology, Indian Council for Medical Research). Establishing a screening programme is problematic in a setting where those women most at risk (i.e. older women) are unlikely to attend public sector health care settings (which are predominantly for maternal and child health care), and the concept of screening is not documented.

... the country has some of the most well known and potentially successful interventions to slow the spread of STIs, including HIV...

\subsection{STI prevention and care outside the public sector}

Perhaps as a result of a stimulating and innovative NGO climate, the country has some of the most well known and potentially most successful interventions to slow the spread of STIs, including HIV, in groups at higher risk of infection. The types of interventions undertaken range from promotion of IEC material, through provision of health services (including STI services), to home-based care for people with HIV/AIDS. Possibly the best known is an intervention among sex workers in Kolkata. Known as 'Sonagachi' (after the district in the city where many of the brothels are located), this intervention has become globally recognised for the innovative approach it has taken to risk reduction. Recognising that sexual behaviour is not determined by individualled parameters alone, the intervention has sought to address a wide range of social, economic, health and other concerns of the women working in the brothels. Activities such as non-formal education, children's immunisation, cultural programmes, promotion of self-employment and vocational training, legal training, and activities targeted at clients have all been supported in Sonagachi. The project is now run largely from within the brothel community, and has succeeded in a number of areas - increased literacy being one of the major achievements. HIV rates in women selling sex in the Sonagachi area have remained relatively stable, and are currently at 
around 5\%. Rates of other STIs have fallen during the lifetime of the project ${ }^{164}$. These figures compare, for example, with data from Mumbai which found an increase in HIV prevalence in female commercial sex workers from $21.1 \%$ to $51 \%$ over the period 1990 to $1994^{165}$.

Other targeted interventions carried out with the assistance of NGOs have concentrated on injecting drug users and people working along highways (truck drivers and their assistants, for example). Injecting drug use has been a significant problem in India's north-east states (bordering Myanmar), and HIV rates among IDU there are currently over $80 \%$. Once thought to be a relatively contained problem, injecting drug use (especially of buprenorphine) is currently thought to be on the increase throughout the country (Dr. S. Panda, personal communication).

\section{Injecting drug use has been a significant problem in India's north-east states (bordering Myanmar), and HIV rates among IDU there are currently over $80 \%$.}

The public sector, through NACO, is committed to partnerships with NGOs, in a variety of ways to interrupt HIV/STI transmission among groups at higher risk ${ }^{141}$. Such partnerships are not limited to intervention activities, but also encompass baseline research to inform programme design. One successful model of government/NGO collaboration in HIV/STI control is found in the southern Indian State of Tamil Nadu where the State AIDS Cell (a government body) was converted into a Registered Society with its own executive committee which includes NGO representatives. The Society monitors the activities of the public sector in HIV control, and also directly funds NGOs to work with both 'risk groups' and the 'general population'. This public sector/NGO cooperation has served as a model to promote similar partnerships in other states in India $^{166}$.

\subsection{Voluntary HIV counselling and testing}

The Government of India policy statement on HIV testing emphasises that no individual should undergo mandatory testing for HIV, adequate voluntary testing facilities with pre- and post-test counselling should be made available throughout the country, and there should be at least one government-run HIV testing centre per district ${ }^{167}$. To implement these objectives, the public 
sector has been collaborating with NGOs that have taken the lead in developing anonymous HIV counselling and testing centres. A model HIV counselling centre, the first of its kind in the country, has been established in a large government hospital in Delhi. This centre is jointly run by NACO, the hospital itself, UNAIDS, and a consortium of six Delhi-based NGOs which provide counselling services. The centre has facilitated the provision of a continuum of care for HIV positive persons through its linkages with other NGOs, community-based organisations, and service providers in the community. ${ }^{168}$ It is reported that this collaborative effort has had an impact on policies and practices throughout the hospital regarding the appropriate use of HIV testing, the protection of the confidentiality of HIV test results, and the right of people living with HIV/AIDS to medical services ${ }^{169}$. The government is planning to make it mandatory to have counselling services, run by an NGO and trained and funded by the State AIDS Cell, in all HIV testing facilities in government medical colleges.

\subsection{Care for people living with HIV/AIDS}

Isolation, stigmatisation, and other forms of discrimination characterise the experience of the vast majority of people living with HIV/AIDS in India and pose severe constraints on their ability to reveal their HIV/AIDS status and avail health care and support. There have been instances where HIV/AIDS patients have been refused admission to hospitals, both government and private. ${ }^{170}$ Indeed, although various measures have been taken by the government, private, and the NGO sectors to provide high quality care and support to people living with HIV/AIDS, studies show that hospitals and other care settings are the main sites where HIV positive people experience discrimination and stigmatisation. ${ }^{171}$

Compounding these disadvantages is the exorbitant cost of most treatment options. For example, although antiretroviral drugs are currently produced by Indian pharmaceutical companies and sold at prices well below those in industrialised countries, only 3-5\% of the known HIV infected individuals are currently able to afford such therapy in India ${ }^{172}$. As a result of widespread influences and beliefs including the perceived incurable nature of HIV infection, advertisements in media promoting dubious cures for HIV/AIDS, myths about side effects of allopathic medicines, and an inability to afford the cost of antiretroviral treatment, the use of 'alternative' medicines is very common among HIV infected people ${ }^{172 .}$

As the absolute number of people living with HIV/AIDS increases, provision of health care and social support has become a more pressing issue, and has been adopted as an integral 
component of the National AIDS Prevention and Control Policy. The measures taken by the government to meet the growing needs for care and support of people living with HIV/AIDS include: provision of free drugs for the management of opportunistic infections in patients at government health care settings; counselling services for HIV infected people; and supporting NGOs and community based organisations in providing hospice care. NACO, in collaboration with the World Health Organization (WHO) and local NGOs, has been conducting pilot programmes on care and support for people living with HIV/AIDS in Manipur, Maharashtra, and Tamil Nadu. Just as in the context of voluntary counselling and testing, the NGO sector has established model care and support programmes for people living with HIV/AIDS in many of the larger cities. Similarly, HIV positive people's support movements such as the Indian Network of Positive People (INP+), though still in their infancy, are undertaking the task of mobilising support. Currently absent from the government programme and the NGO programmes are any subsidies towards the purchase of antiretroviral drugs. 


\section{Expenditure in Health Programmes}

\subsection{Expenditure in one state}

A recent survey of household level expenditures on reproductive and child health $(\mathrm{RCH})$ care in Rajasthan provides a comprehensive look at spending patterns in this field ${ }^{173}$. Whilst the data can never be said to mirror exactly the expenditure patterns in all other states, it may reflect the general trend of where money for health care comes from, and how it is spent. The Rajasthan data (gathered from a random survey of 1100 households in and around the city of Udaipur) show that household expenditure is the largest source of financing in $\mathrm{RCH}$. The State of Rajasthan spends a total of $6 \%$ of its GDP on health care, of which just over $21 \%$ is spent on RCH services. Nonetheless, by far the largest source of financing for health care in Rajasthan comes from household (out-of-pocket) expenditure $-71 \%$ of the total spent on health, and $80 \%$ of expenditure in the RCH sector. Money spent on what is termed 'RTI services', constitutes the third leading use of public sector (government and donor) funds in RCH (after maternity and child health services). At the household level, it constitutes the top expenditure used to purchase all types of $\mathrm{RCH}$ care. In other words, families surveyed in Rajasthan spent more of their own money on seeking care for symptoms of RTIs than they spent on child health care, and all forms of safe motherhood (pre- and post-natal, obstetric, and abortion services).

In the Rajasthan survey, over one-third of women reported an RTI-related symptom in the last three months (abnormal discharge, pain on urination, abdominal pain during sex, or postcoital bleeding). Such a result is similar to that found in other population-based studies ${ }^{124}$ - as referred to above. The caveat to this is that when infective causes have been looked for as the aetiology of these symptoms, they have often not been found. As discussed above, there is a poor correlation between reported morbidity and the presence of laboratory-confirmed infection. Such findings make the reported household-level expenditures on symptoms of RTIs even more disturbing. 


\subsection{Expenditure and allocation for nationwide STI control programmes}

The programmes for prevention and control of STDs are currently an integral part of the overall AIDS control programme. Table 4 shows the allocation of funds for the various components of the AIDS control programme for the period 1992-99. Funding for the HIV/AIDS programme comes from a variety of sources, including Central Government - which has committed \$200 million to NACO over the period 1997-2002. In 1999, the World Bank approved a credit of \$191 million dollars for a five-year HIV/AIDS control programme of activities (with an extra government contribution of $\$ 38$ million, and contributions from other external partners of $\$ 99$ million ${ }^{141}$ ). This large project will prioritise interventions among groups perceived to be at higher risk of infection, but will ensure programme activities for others as well. Donors (bilateral and multilateral) invest heavily in HIV/AIDS and STI control in the country, and there is a strong technical input into the sector from both UN agencies and bilateral donors.

Table 4: Financial Allocation for Components of AIDS Control Programme and Actual Expenditure during the 1990s

\begin{tabular}{|r|r|r|r|r|r|r|r|}
\hline Year & $\begin{array}{r}\text { Programme } \\
\text { management }\end{array}$ & $\begin{array}{c}\text { Blood } \\
\text { safety }\end{array}$ & I.E.C & $\begin{array}{r}\text { Surveillance } \\
\text { \& clinical } \\
\text { management }\end{array}$ & $\begin{array}{r}\text { STI } \\
\text { control }\end{array}$ & $\begin{array}{r}\text { Total } \\
\text { budget } \\
\text { estimates }\end{array}$ & $\begin{array}{r}\text { Actual } \\
\text { expenditure }\end{array}$ \\
\hline $1992-93$ & 1.40 & 4.80 & 5.65 & 2.43 & 1.99 & 16.28 & 6.91 \\
$1993-94$ & 0.71 & 5.25 & 7.59 & 1.85 & 1.56 & 16.98 & 7.61 \\
$1994-95$ & 0.68 & 8.17 & 7.77 & 1.75 & 0.82 & 19.20 & 10.23 \\
$1995-96$ & 0.94 & 6.61 & 8.29 & 1.94 & 0.82 & 18.60 & 12.42 \\
$1996-97$ & 2.66 & 8.99 & 17.58 & 1.99 & 1.57 & 32.79 & 26.61 \\
$1997-98$ & 1.65 & 13.82 & 6.02 & 0.38 & 1.39 & 23.25 & 28.61 \\
$1998-99$ & 1.59 & 10.49 & 6.55 & 4.03 & 3.15 & 25.81 & 25.12 \\
\hline
\end{tabular}

Source ${ }^{16}$

Note: US $\$$ in millions at the exchange rate of 1 US $\$=43$ Rupees

During the 1990s the major expenditures of the HIV/AIDS control programme were in promoting IEC activities and in ensuring blood safety. The prevention and control of STIs received only a small share of the total allocation for HIV/AIDS control. Financial allocation for STI control declined from $12 \%$ of the total financial outlay for HIV/AIDS control in the year 1992-93 to $4-6 \%$ during the year 1994-98. However, the year 1998-99 witnessed an increased financial allocation, perhaps, a reflection of the increased acknowledgement by policy makers of crucial links between STIs and HIV. 
At present, clinical management of people with HIV/AIDS and surveillance for these infections together receive less than one-sixth of the AIDS control programme budget, however this is a substantial rise on the immediately preceding years' expenditures. This figure may be expected to rise in the future; not only will the number of people requiring clinical care increase, but the local cost of anti-AIDS drugs is also expected to rise. The recent World Trade Organisation/ Trade Related Intellectual Property Rights (WTO/TRIPS) agreement may have the potential to compromise the ability of local Indian companies to produce cheaper versions of effective drugs. For example, the current local cost of locally produced fluconazole in India is $\$ 55$ for 100 tablets, compared to $\$ 697$ in Malaysia and $\$ 817$ in the Philippines ${ }^{170}$.

It is worthwhile noting that the utilisation of funds allocated for HIV/AIDS control has been sub-optimal until very recently. For example, only around fifty $\%$ of the total allocation for HIV/AIDS control was utilised during 1992-95. 


\section{Conclusion}

India, united through many aspects, displays remarkable diversity - perhaps at a level to be expected given the size and scale of the country and its population. Such diversity is apparent from even a cursory review of the known epidemiology of STIs in India. With published rates ranging from $0.5 \%$ to $28.7 \%$ of women in community-based studies infected with chlamydia, it is hard to overestimate the scale of the challenge faced by policy makers and programme managers charged with designing effective, accessible, and affordable programmes for STI control in the country. There is no 'Indian scenario' of sexually transmitted infections, including HIV, per se. In its place there is a complex interplay and overlap of different STI/HIV epidemics at different stages of development, with varied underlying causes, which need to be addressed by different system-level interventions. Nonetheless, there are common challenges throughout India for the design of appropriate responses to the problem of STI control in the country. These are not only the common themes of poverty, illiteracy, and gender-based disparities, but some features which are specific to the STI situation in India. These can be summarised as follows:

\section{Epidemiological evidence}

1. Lack of epidemiological data. There is currently no functioning surveillance system (active or passive, using primary or secondary data sources, and no data collection from the majority of providers - the private sector) for STIs in India. Programme managers at both state and local levels often have no idea of the exact burden of STI-related disease in the communities they are serving. Extrapolating results from one part of the country to another is fraught with difficulties. Similarly, there are no data available to show trends of STI data with time. These problems are exacerbated in the case of men where even less is known about the burden of STI-related disease.

2. Current data sets are flawed by a lack of standardisation. Even when data exist on the STI situation in a particular geographical area, comparisons with results from other studies are 
difficult given the highly divergent nature of the study and laboratory methods. The challenge for both researchers and surveillance managers is to ensure a standardisation of methods in the future.

\section{Evidence for risk and protective behaviour}

3. Poor knowledge of sexual networks. Sexual behaviour research is very much in its infancy in India. There is scant understanding of both the quantitative and qualitative nature of sexual behaviour in the country. The concept of sexual network research has not yet been put into practice, although it has been discussed on some research agendas.

4. Understanding health care seeking. Whilst we know something about patterns of health care seeking, the underlying motivations (and, hence, opportunities to intervene) are less well understood. The role of a wide variety of possible influences (monetary, geographical, genderbased personal relations, perceptions on the quality of care, etc) have yet to be appreciated in relation to people choosing health care providers for STI/RTI symptoms.

\section{Effectiveness of care}

5. Appropriate health-care interventions not yet defined. In the public sector, much attention has been focused on the promotion of case management strategies for symptomatic people with possible STIs. There has been remarkably little research on the effectiveness of this strategy clinical effectiveness, cost-effectiveness, operational effectiveness. Such research is vital in a country where the prevalence of the infections being targeted is not well understood, there is a large cultural overlay to reported symptoms, and the ability of the primary health care system to integrate STI management has not been assessed. Further, there has been a tendency to concentrate on aspects of case management and overlook other strategies in STI control (such as antenatal syphilis screening, or screening for cervical cancer). In many cases, these other aspects of STI control have been shown to be highly cost-effective strategies, but have failed to gain a high place on the public health agenda. Thus, for example, the case of materno-fetal transmission: India has had a policy for antenatal syphilis screening since the 1950s, but this has never been operationalised nationally. This can be contrasted, for example, with the current efforts to prevent materno-fetal transmission of HIV.

\section{Structure of the health service}

6. Role of the private sector. Studies throughout India show that the most common sites for seeking health care are outside the public sector. This is true not just for STIs, but for a wide 
variety of reproductive health conditions. Yet, the large and influential private sector remains almost undocumented and virtually unregulated. As a consequence, there is currently little hope of enforcing standards of care (including laboratory support) in the multi-faceted private sector.

7. The reproductive health challenge. Despite all of the above caveats, there is a general consensus that STIs are currently higher on the policy and research agenda than at any time in the recent past. In part this may be due to the impetus provided by the HIV epidemic, but it is also fuelled by the very public government commitment to abandon long-held family planning targets and develop a comprehensive reproductive health care programme which includes integrated STI/RTI care. Moving beyond the rhetoric, which has now been clearly articulated and agreed upon, presents an even larger challenge to the health service: which populations should be reached, with which services, and, fundamentally, how much will this cost? The challenge now is to answer these and many other questions in India in a way that pre-empts the development of an even greater threat fuelled by the fear of an HIV epidemic, but also retains relevance to locally defined situations.

8. Resource allocation. We have seen that although funds may be committed to STI control, they have not always been used. Further, there is little published documentation in current use to assist policy makers and programme managers in making rational choices concerning the appropriate resource allocation given their current epidemiological, cultural and economic situation.

\section{A vulnerable population}

9. A poorly educated population. India faces enormous challenges in dealing with the high levels of illiteracy in the country. This carries with it specific challenges for IEC primary prevention campaigns, but innovative approaches to mass communication have been adopted with success on other issues, including reproductive health issues.

10. Structural inequalities. The United Nations International Conference on Population and Development held in 1994 articulated the fundamental link between structural/macro-factors and reproductive health goals. As we have seen throughout this paper, vast numbers of people in India are severely disadvantaged in terms of income, education, power structures, and gender. Addressing these basic issues of human rights lies at the core of achieving better health outcomes (including reproductive and infectious diseases) in India. Such a challenge is formidable both in terms of required scope and coverage, but lies at the heart of improving health for the greatest number of people in India. 


\section{References}

${ }^{1}$ Wasserheit, J. N. 1991. Epidemiological synergy: Interrelationships between HIV infection and other STDs. In L. C. Chen, J. Sepulveda, and J. Segal (eds.), AIDS and Women's Health: Science for Policy and Action. New York: Plenum Press, pp. 47-72.

${ }^{2}$ International Institute for Population Sciences. 1995. National Family Health Survey (MCH and Family Planning), India 1992-93. Bombay: IIPS.

${ }^{3}$ Srinivasan, K. 1996. An overview of demographic transition in India since 1970. In K Srinivasan (ed.), Population Policy and Reproductive Health. New Delhi: Hindustan Publishing Corporation, pp. 3-66.

${ }^{4}$ Registrar General and Census Commissioner, India. 2001. http://www.censusindia.net

${ }^{5}$ Ainsworth, M., Fransen, L. and Over, M. 1998. Confronting AIDS: Evidence from the developing world. The European Commission and The World Bank.

${ }^{6}$ United Nations Development Programme. 1999. Human Development Report 1999. New York: Oxford University Press.

${ }^{7}$ Government of India. 2000. Economic Survey 1999-2000. New Delhi: Government of India Press.

${ }^{8}$ World Bank. 1997. World Development Report. New York: Oxford University Press. Quoted in ul Haq, M. and Haq, K. 1998. Human Development in South Asia. Karachi: Oxford University Press.

${ }^{9}$ United Nations Children's Fund. 1999. The State of the World's Children 1999. New Delhi: Model Press.

${ }^{10}$ Jetley, S. 1987. Impact of male migration on rural females. Economic and Political Weekly 22(44): WS47-53. 
${ }^{11}$ Ramasubban, R. 1992. Sexual behaviour and conditions of health care: Potential risks for HIV transmission in India. In T, Dyson. (ed.), Sexual Behaviour and Networking: Anthropological and Socio-Cultural Studies on the Transmission of HIV. Liege: Derouaux-Ordina. pp. 175-202.

12 Shariff, A. 1999. India: Human Development Report A Profile of Indian States in the 1990s. New Delhi: Oxford University Press.

${ }^{13}$ International Institute for Population Sciences and ORC Macro. 2000. National Family Health Survey (NFHS-2), 1998-99, India. Mumbai: IIPS.

${ }^{14}$ Ministry of Health and Family Welfare. 2000. http://mohfw.nic.in/helindi.html.

${ }^{15}$ World Bank. 1993. World Development Report: Investing in Health. New York: Oxford University Press.

${ }^{16}$ National AIDS Control Organisation. 1998. Country Scenario 1997-98. Government of India, New Delhi: Ministry of Health and Family Welfare.

${ }^{17}$ Rowley, J. and Berkley, S. 1998. Sexually transmitted diseases. In C. J. L. Murray and A. D. Lopez (eds.), Health Dimensions of Sex and Reproduction - The Global Burden of Sexually Transmitted Diseases, HIV, Maternal Conditions, Perinatal Disorders, and Congenital Anomalies. The Harvard School of Public Health, on behalf of WHO and World Bank, Harvard University Press, pp. 19-110.

${ }^{18}$ World Health Organization. 1999. DALYs and Reproductive Health: Report of an informal consultation, 27-28 April 1998. WHO/RHT/98.28, Geneva: WHO.

${ }^{19}$ Bulut, A., Yolsa, N., Filippi, V. and Graham, W. 1995. In search of truth: Comparing alternative sources of information on reproductive tract infection. Reproductive Health Matters 6:31-39.

${ }^{20}$ AIDS Prevention and Control Project (APAC). 1998. Community Prevalence of Sexually Transmitted Diseases in Tamil Nadu 1998 - A Report. AIDS Prevention and Control Project.

${ }^{21}$ Bang, A. T., Bang, R. A., Baitule, M., and Phirke, K. (not dated). High Prevalence and Wide Spectrum of Reproductive Morbidities in Males in Gadchiroli, India (unpublished).

${ }^{22}$ Singh, K. G., Joshi, M. K. and Bajaj, A. K. 1990. Pattern of sexually transmitted diseases in Allahabad. Indian Journal of Sexually Transmitted Diseases 11:6-8.

${ }^{23}$ Bhujwala, R. A., Mishra, B., Bhargava, N. C., Gupta, A., Pandhi, R. K., Seth, P. and Ganguli, D. D. 1984. Non-gonococcal urethritis in men and its response to therapy. Indian Journal of Medical Research 79:728-732. 
${ }^{24}$ Sharma, M., Nayak, N., Malhotra, S., Kumar, B. and Hemal, A. 1989. Chlamydiazyme test for rapid detection of Chlamydia trachomatis. Indian Journal of Medical Research 89:4-11.

${ }^{25}$ Kamat, H. A. and Banker, D. D. 1993. Human immunodeficiency virus-1 infection among patients with sexually transmitted diseases in Bombay. The National Medical Journal of India 6(1):11-13.

${ }^{26}$ Chopra, A., Mittal, R. R., Singh, P. and Sharma, P. 1990. Patterns of sexually transmitted diseases at Patiala. Indian Journal of Sexually Transmitted Diseases 11:43-45.

${ }^{27}$ Risbud, A., Chan-Tack, K., Gadkari, D., Gangakhedkar, R. R., Shepherd, M. E., Bollinger, R., Mehendale, S., Gaydos, C., Divekar, A., Rompalo, A. and Quinn, T. C. 1999. The etiology of genital ulcer disease by multiplex polymerase chain reaction and relationship to HIV infection among patients attending sexually transmitted disease clinics in Pune, India. Sexually Transmitted Diseases 26(1):55-62.

${ }^{28}$ Chaudhary, S. D., Bhattia, K. K., Bansal, R. K. and Jain, V. K. 1988. Pattern of sexually transmitted diseases in Rohtak. Indian Journal of Sexually Transmitted Disease 9:4-7.

${ }^{29}$ George, S., Jacob, M., John, T. J., Jain, M. K., Nathan, N., Rao, P. S. S., Richard, J. and Antonisamy, B. 1997. A case-control analysis of risk factors in HIV transmission in South India. Journal of Acquired Immune Deficiency Syndromes and Human Retrovirology 14:290-293.

${ }^{30}$ Kumar, V., Garg, B. R. and Baruah, M. C. 1990. A clinical study of genital ulcers. Indian Journal of Sexually Transmitted Diseases 11:15-18.

${ }^{31}$ Kumar, P., Sharma, N. K., Sharma, U., Sharma, R.P., Idnani, R. and Agarwal, A. K. 1990. Trichomoniasis and candidiasis in consorts of females with vaginal discharge. Indian Journal of Sexually Transmitted Diseases 11:54-56.

${ }^{32}$ Garg, S., Sharma, N., Bhalla, P., Sahay, R., Saha, R., Raina, U., Das, B.C., Sharma, S. and Murthy, N.S. 2000. Reproductive Morbidity in an Indian Urban Slum: Need for Health Action. Paper presented at the Workshop on Reproductive Health in India: New Evidence and Issues, Pune, February 28-March 1.

${ }^{33}$ Bhatia, J. C., Cleland, J., Bhagavan, L. and Rao, N. S. N. 1997. Levels and determinants of gynaecological morbidity in a district of south India. Studies in Family Planning 28(2): 95103.

${ }^{34}$ Parikh, I., Taskar, V., Dharap, N. and Mulgaonkar, V. (not dated). Gynaecological Morbidity among Women in a Bombay Slum (unpublished report). 
${ }^{35}$ Prasad, J. H., George, V., Lalitha, M. K., Jayapaul, M. N. R., Abraham, S., Shetty, N. and Joseph, A. 2000. Prevalence of Reproductive Tract Infection among Adolescents in a Rural Community in Tamil Nadu. Paper presented at the Workshop on Reproductive Health in India: New Evidence and Issues, Pune, February 28-March 1.

${ }^{36}$ Santhya, K. G. 1999. Factors Affecting Reproductive Tract Infections in Southern India. Ph.D. Thesis submitted at Flinders University, South Australia (unpublished).

${ }^{37}$ Chhabra, S., Swarup, G., Swarup, K. and Jajoo, U.N. 1991. Correlation of cervical abnormalities with abnormal smears in mass screening programme of cervical cytology. Journal of Obstetrics and Gynaecology of India 41(5): 681-683.

${ }^{38}$ Bang, R., Bang, A. T., Baitule, M., Choudhary, Y., Sarmukaddam, S. and Tale, O. 1989. High prevalence of gynaecological diseases in rural Indian women. The Lancet 8629:85-87.

39 Oomman, N. 1996. Poverty and Pathology: Comparing Rural Rajasthani Women's Ethnomedical Models with Biomedical Models of Reproductive Morbidity: Implications for Women's Health in India. Ph.D Thesis submitted at Johns Hopkins University, Baltimore, USA. (unpublished).

${ }^{40}$ Gangakhedkar, R. R., Bentley, M. E., Divekar, A. D., Gadkari, D., Mehendale, S. M., Shepherd, M. E., Bollinger, R. C. and Quinn, T. C. 1997. Spread of HIV infection in married monogamous women in India. Journal of the American Medical Association 278(23):2090-2092.

${ }^{41}$ Jana, S., Bandyopadhyay, N., Mukherjee, S., Dutta, N., Basu, I. and Saha, A. 1998. STD/ HIV intervention with sex workers in West Bengal, India. AIDS 12(suppl B): S101-S108.

${ }^{42}$ Urmil, A. C., Dutta, P. K., Basappa, K. and Ganguly, S. S. 1989. A study of morbidity pattern among prostitutes attending a municipal clinic in Pune. Journal of Indian Medical Association 87(2): 29- 31.

${ }^{43}$ Pal, A., Ghosh, U. K., Ganguli, G., Baveja, R., Dayal, M. and Pandey, R.C. 1993. Sociodemographic profile of sexually transmitted diseases in females. Journal of Obstetrics and Gynaecology of India 43(3):388-390.

${ }^{44}$ Chaudhuri, P. and Iyengar, R. 1994. Chlamydia trachomatis infection in a south Indian population - A prospective pilot study. Journal of Obstetrics and Gynaecology of India 44(4): 593-594.

${ }^{45}$ Bhatnagar, P., Kashyap, V., Das, D. K., Murthy, N. S. and Luthra, U. K. 1991. Clinicoepidemiological study of condylomatous lesions in inflammatory smears. Journal of Obstetrics and Gynaecology of India 41(6):793-798. 
${ }^{46}$ Dhall, K., Sarkar, A., Sokhey, C., Dhall, G. I. and Ganguly, N. K. 1990. Incidence of gonococcal infection and its clinicopathological correlation in patients attending gynaecological out patient department. Journal of Obstetrics and Gynaecology of India 40(3):410-413.

${ }^{47}$ Parashari, A., Singh, V., Sodhani, P., Satyanarayana, L., Chattopadhya, D., Gupta, M. M. and Seghal, A. 1994. Clinical and aetiological profile of reproductive tract infections (RTIs) among women attending gynaecology out-patient department of a major city hospital in Delhi. Journal of Obstetrics and Gynaecology of India 44(5):790-797.

${ }^{48}$ Misra, J. S., Das, K., Tandon, P. and Harish, A. 1992. Sexually transmitted pathogens and cervical carcinogenesis. Journal of Obstetrics and Gynaecology of India 42(3):380-383.

${ }^{49}$ Joshi, J. V., Palayekar, S., Hazari, K. T., Shah, R. S. and Chitlange, S. M. 1994. The prevalence of Chlamydia trachomatis in young women. The National Medical Journal of India $7(2): 57-59$.

${ }^{50}$ Mali, JJ-B., Hazari, K., Chitlange, S. and Shah, R. 1991. Abnormal Cytology indicating sexually transmitted diseases in women attending family welfare clinics. Journal of Obstetrics and Gynaecology of India 41(4):521-524.

${ }^{51}$ Gogate, A., Deodhar, L., Bhatt, R. and Vaidya, P. 1990. Mycoplasma hominis infections in female genital tract and use of immunofluorescence for antibody detection. Indian Journal of Medical Research 91(A):364-367.

52 Jayarao, P., Gogate, A., Deodhar, L. and Vaidya, P. R. 1989. Trichomoniasis: A clinical and laboratory evaluation. Journal of Obstetrics and Gynaecology of India 39(6):829-833.

${ }^{53}$ Mishra, D., Singh, G. and Sharma, D. 1988. Unsuspected gonococcal infection, candidiasis and trichomoniasis in females. Indian Journal of Sexually Transmitted Diseases 9:25-28.

${ }^{54}$ Sinha, G. 1994. The prevalence of wart virus infection and its association with premalignant lesions of the cervix. Journal of Obstetrics and Gynaecology of India 44(6): 931-935.

${ }^{55}$ Singh, N. G. B., Devi, Y.L., Singh, H. L., Singh, S. I., Sharma, C. H. N., Singh, Y. I. and Singh, K. H. J. 1992. Incidence of HIV (Human immunodeficiency virus) infection and VDRL reactivity among pregnant women. Journal of Obstetrics and Gynaecology of India 42(5):576580 .

${ }^{56}$ Hira, S. K. 1991. Guidelines for Prevention of Adverse Outcomes of Pregnancy due to Syphilis. Geneva: World Health Organization. 
${ }^{57}$ Kunte, A., Misra, V., Paranjape, R., Manusukhani, N., Padbidri, V., Gonjari, S., Kakrani, V., Thakar, M. and Mehendale, S. 1999. HIV seroprevalence and awareness about AIDS among pregnant women in rural areas of Pune district, Maharashtra, India. Indian Journal of Medical Research 110:115-122.

${ }^{58}$ Gupta, M. K., Thergaonkar, W. P. and Chawla, N. 1998. Anonymous testing of HIV infection in pregnant women. Journal of Communicable Diseases 30(2):121-122.

${ }^{59}$ Vishwanath, S., Talwar, V., Prasad, R., Coyaji, K., Elias, C. and de Zoysa, I. 1998. The Assessment and Management of Vaginal Discharge - A Study among Symptomatic Women in a Family Planning Clinic in East Delhi. New Delhi: Population Council.

${ }^{60}$ Deb, M., Kaur, T. P., Prakash, K. and Verma, A. 1989. Incidence of Gardnerella vaginalis in non specific vaginitis. Journal of Obstetrics and Gynaecology of India 39(1):88-92.

${ }^{61}$ Pandit, D. V., Bhatt, R. R., Karnad, J. M. and Deodhar, L. P. 1993. Microbial screening of females with vaginitis. Journal of Obstetrics and Gynaecology of India 43(2):244-247.

${ }^{62}$ Chhabra, S., Aher, K., Narang, P. and Gagane, N. 1993. Chlamydia trachomatis infection and cervical intraepithelial neoplasia. Journal of Obstetrics and Gynaecology of India 43(1):93-94.

${ }^{63}$ Kar, J., Agarwal, P. L., Mishra, S. D. and Jina, R. 1988. Vaginal cytology in erosion of cervix and cervicitis. Journal of Obstetrics and Gynaecology of India 38(1): 100-105.

${ }^{64}$ Bhujwala, R. A., Biswas, T. D., Bhargava, V., Dang, N. and Chaudhry, R. 1988. Detection of chlamydial and gonococcal antibodies in women with pelvic inflammatory disease and infertility - an aid to diagnosis. Journal of Obstetrics and Gynaecology of India 38(1):96-99.

${ }^{65}$ Chhabra, S. and Fali, L. 1992. Clinical genital infection in infertile women with Chlamydia trachomatis infection. Journal of Obstetrics and Gynaecology of India 42(1):68-70.

${ }^{66}$ Kushtagi, P., Rao, K., Abraham, E. and Shivananda, P. G. 1991. Prevalence of antibodies to Chlamydia trachomatis among infertile couples. Journal of Obstetrics and Gynaecology of India 41(5):671-673.

${ }^{67}$ Brabin, L., Gogate, A., Gogate, S., Karande, A., Khanna, R., Dollimore, N., deKoning, K., Nicholas, S. and Hart, C.A. 1998. Reproductive tract infections, gynaecological morbidity and HIV seroprevalence among women in Mumbai, India. Bulletin of the World Health Organization 76(3):277-287. 
${ }^{68}$ Char, A. and Vaidya, S. 2000. Gynaecological morbidity among women seeking sterilization services in rural Maharashtra. Paper presented at the Workshop on Reproductive Health in India: New Evidence and Issues, Pune, February 28-March 1.

${ }^{69}$ Luthra, U. K., Mehta, S., Bhargava, N. C., Ramachandran, P., Murthy, N. S., Seghal, A. and Saxena, B. N. 1992. Reproductive tract infections in India: The need for comprehensive reproductive health policy and programs. In A. Germain, K. K. Holmes, P. Piot and J. N. Wasserheit (eds.), Reproductive Tract Infections: Global Impact and Priorities for Women's Reproductive Health. New York: Plenum Press, pp. 317-42.

${ }^{70}$ Singh, J., Bhatia, R., Gandhi, J. C. et al. 1998. Outbreak of hepatitis B in a rural community in India linked to inadequately sterilised needles and syringes. Bulletin World Health Organization 76(1):93-8.

${ }^{71}$ Singh, S., Dwivedi, S. N., Sood, R. and Wali, J. P. 2000. Hepatitis B, C and HIV infection in multiply-injected kala-azar patients in Delhi. Scandinavian Journal of Infectious Disease 32(1):3-6.

${ }^{72}$ Chowdhury, A., Santra, A., Chaudhuri, S., Ghosh, A., Banerjee, P. and Mazu, D. N. 1999. Prevalence of hepatitis B infection in the general population: Rural community-based study. Tropical Gastroenterology 20(2):75-7.

${ }^{73}$ Tandon, B. N., Acharya, S. K. and Tandon, A. 1996. Epidemiology of hepatitis B virus infection in India. Gut 38(suppl 2):S56-S59.

${ }^{74}$ Aggarwal, R. and Naik, S. R. 1994. Prevention of hepatitis B infection: The appropriate strategy for India. National Medical Journal of India 7(5):216-220.

${ }^{75}$ Van Damme, P., Kane, M. and Meheus, A. 1997. Integration of hepatitis B vaccination into national immunisation programmes. British Medical Journal 314:1033-1036.

${ }^{76}$ Miller, M. A. and Kane, M. 2000. Routine hepatitis B immunisation in India: Costeffectiveness assessment, Indian Journal of Paediatrics. 67(4):299-300.

${ }^{77}$ National AIDS Control Organisation. 2000. http://www.naco.nic.in/vsnaco/indianscene/ update.html\#7

${ }^{78}$ National AIDS Control Organisation. 2000.

http://www.naco.nic.in/vsnaco/indianscene/update.html (date 07/09/00)

${ }^{79}$ Pal, S. C., Sarkar, S., Naik, T. N., Singh, P. K., Tushi, A. S., Lal, S. and Tripathy, S. P. 1990. Explosive epidemic of HIV infection in north-eastern states of India, Manipur and Nagaland. Indian Council for Medical Research. CARC Calling, 3:2-6. 
${ }^{80}$ Rodrigues, J. J., Mehendale, S. M., Shepherd, M. E., Divekar, A. D., Gangakhedkar, R. R., Quinn, T. C., Paranjape, R. S., Risbud, A. R., Brookmeyer, R. S., Gadkari, D. A., Gokhale, M. R., Rompalo, A. M., Deshpande, S. G., Khalandkar, M. M., Mawar, N. and Bollinger, R. C. 1995. Risk factors for HIV infection in people attending clinics for sexually transmitted diseases in India. British Medical Journal 311:283-286.

${ }^{81}$ Mehendale, S. M., Shepherd, M. E., Divekar, A. D., Gangakhedkar, R. R., Kamble, S. S., Menon, P. A., Yadav, R., Risbud, A. R., Paranjape, R. S., Gadkari, D. A., Quinn, T. C., Bollinger, R. C. and Rodrigues, J. J. 1996. Evidence for high prevalence and rapid transmission of HIV among individuals attending STD clinics in Pune, India. Indian Journal of Medical Research 104:327-335.

${ }^{82}$ Divekar, A. A., Gogate, A. S., Shivkar, L. K., Gogate, S. and Badhwar, V. R. 2000. Disease prevalence in women attending the STD clinic in Mumbai (formerly Bombay), India. International Journal of STD \& AIDS 11(1):45-48.

${ }^{83}$ Mathai, R., Prasad, P. V. S., Jacob, M., Babu, P. G. and John, T. J. 1990. HIV seropositivity among patients with sexually transmitted diseases in Vellore. Indian Journal of Medical Research 91[A]:239-241.

${ }^{84}$ Mohamed, M., Ravinathan, R., Johnson, M., Padmarajan, S. and Jayapaul, K. 1990. HIV transmission among the married women Abstract \#3053 VI International Conference on AIDS, San Francisco, June 23-24 6: 415.

${ }^{85}$ Sarkar, S., Panda, S., Das, N., Naik, T., Sarkar, K., Singh, B.C., Ralte, J. M., Ayer, S. M. and Tripathy, S.P. 1993. Rapid spread of HIV among injecting drug users of north-eastern India. CARC Calling, Bulletin of the Centre for AIDS Research and Control 6:23-28.

${ }^{86}$ John, T. J., Bhushan, N., Babu, P.G., Seshadri, L., Balasubramanium, N. and Jasper, P. 1993. Prevalence of HIV infection in pregnant women in Vellore region. Indian Journal of Medical Research 97:227-230.

${ }^{87}$ Jacob, M., John, T. J., George, S., Rao, P.S. and Babu, P.G. 1995. Increasing prevalence of human immunodeficiency virus infection among patients attending a clinic for sexually transmitted diseases. Indian Journal of Medical Research 101:6-9.

${ }^{88}$ National AIDS Control Organisation. 2000. http:// www.naco.nic.in/vsnaco/indianscene/ indscen.htm.

${ }^{89}$ Nag, M. 1996. Sexual Behaviour and AIDS in India. New Delhi: Vikas Publishing.

${ }^{90}$ Weeramunda, A. J. 1996. NGOs Working with Sex Workers - A Personal Perspective. New Delhi: UNDP Regional Project on HIV and Development. 
${ }^{91}$ National AIDS Control Organisation. 1997. A Summary of the Findings of the High Risk Behaviour Study from 18 Cities. Government of India, Ministry of Health and Family welfare, New Delhi: NACO.

${ }^{92}$ Ghosh, M. and Das, N. K. 1990. Anonder Opekshay: Chondalika Ekdal Khokkosh (in Bengali), Calcutta Development Dialogue, Calcutta cited in Nag, M. 1996. Sexual Behaviour and AIDS in India. New Delhi: Vikas Publishing.

${ }^{93}$ Jana, S. 1992. No title, Abstract published in the $2^{\text {nd }}$ International Congress on AIDS in Asia and the Pacific, Randwick, Australia, AIDS society of Asia and the Pacific, pp. 105 cited in Nag, M. 1996. Sexual Behaviour and AIDS in India. New Delhi: Vikas Publishing.

${ }^{94}$ Jana, S. 1995. Three years stint at Sonagachi: An exposition', Paper distributed at the Indo-US Workshop on Behavioural Research Priorities: Developing Effective Strategies for the Prevention of HIV in India, Tata Institute of Social Sciences, Mumbai, 24-29 April cited in Nag, M. 1996. Sexual Behaviour and AIDS in India. New Delhi: Vikas Publishing.

${ }^{95}$ Collumbien, M., Das, B., Bohidar, N. and Pelto, P. 2000. Male sexual behaviour in Orissa. Paper presented at the Workshop on Reproductive Health in India: New Evidence and Issues, Pune, February 28- March 1.

${ }^{96}$ Pelto, P. J., Joshi, A. and Verma, R. 2000. Development of Sexuality and Sexual Behaviour among Indian Males: Implications for the Reproductive Health Programme. New Delhi: Population Council.

${ }^{97}$ Rakesh, A. 1992. Premarital Sexual Attitudes and Behaviour among Adolescent Girls. Jaipur: Printwell.

${ }^{98}$ Seghal, V. N., Sharma, A. K. and Bhattacharya, S. N. 1992. K.A.B.P. study on AIDS among school boys. Abstract published in the 2nd International Congress on AIDS in Asia and the Pacific, Randwick, Australia. AIDS Society of Asia and the Pacific, pp. 192.

${ }^{99}$ Goparaju, L. 1994. Discourse and practice: Rural-urban differences in male students' sexual behaviour in India. Paper prepared for the IUSSP seminar on Sexual Subcultures, Migration and AIDS, Thailand, 27 February- 3 March cited in Nag, M. 1996 Sexual Behaviour and AIDS in India. New Delhi: Vikas Publishing.

${ }^{100}$ Savara, M. and Sridhar, C. R. 1994. Report on a Survey of Sexual Behaviour Patterns and Attitudes amongst Men and Women in Maharashtra. Bombay: Shakti.

${ }^{101}$ Kaur, U., Sahni, S. P., Bambery, P., Kumar, B., Chauhan, A., Chawla, Y. K. and Dilawari, J. B. 1996. Sexual behaviour, drug use and hepatitis B infection in Chandigarh students. The National Medical Journal of India 9(4):156-159. 
${ }^{102}$ Rangaiyan, G. 1996. Sexuality and Sexual Behaviour in the Age of AIDS: A Study among College Youth in Bombay. Doctoral thesis submitted at International Institute for Population Sciences, Mumbai.

${ }^{103}$ Mathai, R., Ross, M. W. and Hira, S. 1997. Concomitants of HIV/STD risk behaviours and intention to engage in risk behaviours in adolescents in India. AIDS Care 9(5):563-576.

${ }^{104}$ Singh, K. K., Bloom, S. S. and Tsui, A.O. 1998. Husbands' reproductive health knowledge, attitudes, and behaviour in Uttar Pradesh, India. Studies in Family Planning 29(4):388-399.

105 Suchdev, P, 1998. Sex on campus: A preliminary study of knowledge, attitudes, and behaviour of university students in Delhi, India. Journal of Biosocial Science 30:95-105.

${ }^{106}$ Savara, M. and Sridhar, C. R. 1992. Sexual behaviour of urban, educated Indian men: Results of a survey. The Journal of Family Welfare 38:30-43.

${ }^{107}$ Balaganesh, G., Ramakrishnaiah, Y., Rao, S. Y. and Babu, S. V. 1993. A study on the awareness about AIDS/STD in Indian communities. Indian Journal of Sexually Transmitted Diseases 14:38-43.

${ }^{108}$ Balachandar, G., Raghavan, S. S. and Rajaram, P. 1994. Gynaecological problems in adolescents. Journal of Obstetrics and Gynaecology of India 44(4):599-604.

${ }^{109}$ Kumar, A., Mehra, M., Badhan, S. K. and Gulati, N. 1997. Heterosexual behaviour and condom usage in an urban population of Delhi, India. AIDS Care 9(3):311-318.

${ }^{110}$ Basu, D. P. 1994. Appropriate methodologies for studying sexual behaviour in India. The Indian Journal of Social Work LV(4):573-588.

${ }^{111}$ Carolina Population Centre. 1997. Uttar Pradesh Male Reproductive Health Survey 1995-1996. Carolina Population Center, North Carolina.

${ }^{112}$ Narayan, V. 1984. Venereal Diseases: A Social Dilemma. New Delhi: Cosmo.

${ }^{113}$ Rao, A., Nag, M., Mishra, K. and Dey, A. 1994. Sexual behaviour patterns of truck drivers and their helpers in relation to female sex workers. The Indian Journal of Social Work LV(4):603-615.

${ }^{114}$ Siddappa, K., Kumar, V. J. and Ravindra, K. 1990. Pattern of STDs at Davangere. Indian Journal of Sexually Transmitted Diseases 11:39-42.

${ }^{115}$ Jejeebhoy, S. 1998. Adolescent sexual and reproductive behaviour: A review of the evidence from India. Social Science and Medicine 46(10):1275-1290. 
116 Sharma, V. and Sharma, A. 1997. Adolescent boys in Gujarat, India: Their sexual behaviour and their knowledge of acquired immunodeficiency syndrome and other sexually transmitted diseases. Journal of Developmental and Behavioural Paediatrics 18(6):399-404.

${ }_{117}$ Srikanth, P., John, T. J., Jeyakumari, H., Babu, P. G., Mathai, D., Jacob, M., Cherian, A. M., Ganesh, A. and Zachariah, A. 1997. Epidemiological features of acquired immunodeficiency syndrome in southern India. Indian Journal of Medical Research 105:191-197.

118 Jacob, M., Rao, P. S. S., Sridharan, G. and John, T. J. 1989. Epidemiology and clinical profile of genital herpes. Indian Journal of Medical Research 89:4-11.

${ }^{119}$ Khan, S. 1994. Cultural contexts of sexual behaviour and identities and their impact upon preventive models: An overview of South Asian men who have sex with men. The Indian Journal of Social Work LV(4):633-646

${ }^{120}$ Kulkarni, V., Kulkarni, S., Sahasrabudhe, N. and Marathe, M. 2000. Networks, language and sexual behaviours of men who have sex with men in an urban setting. Paper presented at the Workshop on Reproductive Health in India: New evidence and Issues, Pune, India, 28 February1 March.

${ }^{121}$ Pachauri, S. 1999. Moving towards reproductive health: Issues and evidence. In S. Pachauri (ed.), Implementing A Reproductive Health Agenda in India: The Beginning. New Delhi: Population Council, pp.xiii-xlvii.

${ }^{122}$ Asthana, S. and Oosvogels, R. 1996. Community participation in HIV prevention: Problem and prospects for community-based strategies among female sex workers in Madras. Social Science and Medicine 43(2):133-148.

${ }^{123}$ Mishra, R. 1998. STDs and HIV/AIDS: A KAP study among drug operators. Health for the Millions Sept-Oct:11-13.

${ }^{124}$ Koenig, M., Jejeebhoy, S., Singh, S. and Sridhar, S. 1996. Undertaking Communitybased Research on the Prevalence of Gynecological Morbidity: Lessons from India. Paper presented at the IUSSP Seminar on Innovative Approaches to the Assessment of Reproductive Health, Manila, the Philippines, September 24-27.

${ }^{125}$ Elias, C., Low, N. M. and Hawkes, S. (not dated). Clinical definitions of gynecological morbidity relating to infections of the reproductive tract. Undertaking community surveys of gynaecological morbidity. In S. Jejeebhoy, M. Koenig, and I. Shah (eds.), forthcoming, WHO publication.

126 Trollope-Kumar, K. 2000. "Dhatu loss" among women in south Asia: Clinical and epidemiological considerations (unpublished). 
${ }^{127}$ Lambert, H. 1998. Methods and meanings in anthropological, epidemiological and clinical encounters: The case of sexually transmitted diseases and HIV control and prevention in India. Tropical Medicine and International Health 3(12):1002-1010.

${ }^{128}$ Ravindran, T. K. S. 1995. Women's health situation in a rural poor population in Chengalpattu, Tamil Nadu. In M. DasGupta, L.C. Chen, and T.N. Krishnan (eds.), Women's Health in India - Risk and Vulnerabilities, Bombay: Oxford University Press, pp. 175-211.

129 Barua, A. 2000. Reproductive health needs of married adolescent girls in rural Maharashtra. Paper presented at the Workshop on Reproductive Health in India: New Evidence and Issues, Pune, February 28- March 1.

${ }^{130}$ Bhatia, J. C. and Cleland, J. 2000. Perceived gynaecological morbidity, health seeking behaviour and expenditure in Karnataka, India. Paper presented at the Workshop on Reproductive Health in India: New Evidence and Issues, Pune, February 28- March 1.

${ }^{131}$ Joshi, A., Dhapola, M. and Pelto, P. J. 2000. Gynaecological problems: Perceptions and treatment seeking behaviours of rural Gujarati women. Paper presented at the Workshop on Reproductive Health in India: New Evidence and Issues, Pune, February 28- March 1.

132 Oomman, N. 2000. Poverty and pathology: Rajasthani women's perceptions of gynaecological morbidity and their implications for research and prevention. Paper presented at the Workshop on Reproductive Health in India: New Evidence and Issues, Pune, February 28March 1.

${ }^{133}$ Ramasubban, R. and Rishyasringa, B. 2000. Treatment seeking by women in Mumbai slums. Paper presented at the Workshop on Reproductive Health in India: New Evidence and Issues, Pune, February 28- March 1.

${ }^{134}$ Verma, R. K., Rangaiyan, G., Sharma, S., Singh, R. and Pelto, P. J. 2000. A study of sexual health problems and treatment seeking behaviour among men in a slum community. Paper presented at the Workshop on Reproductive Health in India: New Evidence and Issues, Pune, February 28- March 1.

${ }^{135}$ Joseph, A., Srikanth, R. A., Abraham, S., Prasad, J. and John, R. 1998. Sexual behaviour: Older husbands younger wives. Paper presented at the workshop on Men as Supportive Partners in Reproductive and Sexual Health, Kathmandu, Nepal, June 23-26.

${ }^{136}$ Ganguli, D. D., Ramesh, V., Zaheer, S. A., Khatri, R. K. and Bhargava, N. C. 1985. Profile of gonorrhoea in males. Indian Journal of Sexually Transmitted Diseases 6:44-46. 
${ }^{137}$ Bang, R. and Bang, A. 1994. Women's perception of white vaginal discharge: Ethnographic data from rural Maharashtra. In J. Gittelson, M.E. Bentley, P.J. Pelto, M. Nag, S. Pachauri, A.D. Harrison, and L.T. Landman (eds.), Listening to Women Talk about Their Health Issues and Evidence from India. New Delhi: Har-Anand Publications for the Ford Foundation, pp. 79-94.

${ }^{138}$ Ramasubban, R. 1995. Patriarchy and the risks of STD and HIV transmission to women. In M. DasGupta, L.C. Chen, and T.N. Krishnan (eds.), Women's Health in India - Risk and Vulnerabilities. Bombay: Oxford University Press, pp. 212-41.

${ }^{139}$ Patel, B. C., Barge, S., Kolhe, R. and Sadhwani, H. 1994. Listening to women talk about their reproductive health problems in the urban slums and rural areas of Baroda. In J. Gittelsohn, M.E. Bentley, P.J. Pelto, M. Nag, S. Pachauri, A.D. Harrison, and L.T. Landman (eds.), Listening to Women Talk about Their Health Issues and Evidence from India. New Delhi: Har-Anand Publications for the Ford Foundation, pp. 131-44.

${ }^{140}$ United Nations Development Programme. 1999. Human Development Report 1999. New York: Oxford University Press.

${ }^{141}$ World Bank. 1999. Project appraisal document on a proposed credit in the amount of SDR 140.82 million to India for a second national HIV/AIDS control project. World Bank Report No. 18918-IN. Health, Nutrition and Population Sector Unit, South Asia region.

${ }^{142}$ Economic and Political Weekly Research Foundation. 2000. Finances of Government of India. Economic and Political Weekly 35(15):1302-1324.

${ }^{143}$ Walsh, J. A. and Warren, K. S. 1979. Selective primary health care: An interim strategy for disease control in developing countries. New England Journal of Medicine 301:18.

${ }^{144}$ Rifkin, S.B. and Walt, G. 1986. Why health improves: Defining the issues concerning 'comprehensive primary health care' and 'selective primary health care'. Social Science and Medicine 23:559-566.

${ }^{145}$ Qadeer, I. 2000. Health care systems in transition III. India, Part I. The Indian experience. Journal of Public Health Medicine 22(1):25-32.

146 World Bank. 1995. India: Policy and Finance Strategies for Strengthening Primary Health Care Services. World Bank Report No. 13402-IN, May. Quoted in Indian Institute for Health Management (2000) Financing Reproductive and Child Health Care in Rajasthan. New Delhi: USAID.

${ }^{147}$ Pachauri, S. 1995. Defining A Reproductive Health Package for India: A Proposed Framework. New Delhi: Population Council. 
${ }^{148}$ Ministry of Health and Family Welfare. 1999. India's Progress Towards Reproductive Health Goals $(I C P D+5)$. Ministry of Health and Family Welfare, Government of India.

${ }^{149}$ World Bank. 1995. India's Family Welfare Program: Toward a Reproductive and Child Health Approach. Population and Human resources Operations Division, South Asia Country Department.

${ }^{150}$ Ministry of Health and Family Welfare. 2000. http://mohfw.nic.in/infra.htm

${ }^{151}$ Chawla, M. 1996. Dual Job-holding by Public Sector Physicians in India. Boston: Harvard School of Public Health.

${ }^{152}$ Family Health International. 2000. Behavioural Surveillance Surveys Tamil Nadu, India 1996, 1997, 1998. http://www.fhi.org/en/aids/impact/bss/bssr.html

${ }^{153}$ AIDS Prevention and Control Project (APAC). 1999. HIV Risk Behaviour Surveillance Survey in Tamil Nadu-Report on Third Wave 1998. Chennai: APAC-VHS.

${ }^{154}$ Dallabetta, G. A., Gerbase, A. C. and Holmes, K. K. 1998. Problems, solutions, and challenges in syndromic management of sexually transmitted diseases. Sexually Transmitted Infections 74 (Suppl 1):S1-11.

${ }^{155}$ Hawkes, S., Morison, L., Foster, S., Gausia, K., Chakraborty, J., Peeling, R. and Mabey, D. 1999. Managing RTIs in women in low prevalence, low income situations; an evaluation of syndromic management in Matlab, Bangladesh. Lancet 354(9192): 1776-1781.

${ }^{156}$ Sloan, N. L., Winikoff, B., Haberland, N., Coggins, C. and Elias, C. 2000. Screening and syndromic approaches to identify gonorrhoea and chlamydial infections among women. Studies in Family Planning 31(1):55-68.

${ }^{157}$ Hawkes, S., Lee-Jones, L. and Morison, L. 2000. The Costs of Syndromic Management in Different Settings. Draft report to UNAIDS (unpublished).

${ }^{158}$ World Health Organization. 1994. Global Programme on AIDS. Management of sexually transmitted diseases. WHO/GPA./TEM/94.1 Geneva: WHO.

${ }^{159}$ Koenig, M. A. and Khan, M. E. 1999. Improving Quality of Care in India's Family Welfare Programme: The Challenge Ahead. New York: Population Council.

${ }^{160}$ Mertens, T. E., Smith, G. D., Kantharaj, K., Murgditchian, D. and Radhakrishnan, K. M. 1998. Observations of sexually transmitted disease consultations in India. Public Health 11(2):123-128. 
${ }^{161}$ Roy, V., Bhargava, P., Bapna, J.S. and Reddy, B. S. N. 1998. Treatment seeking behaviour in sexually transmitted diseases. Indian Journal of Public Health 42(4):133-135.

${ }^{162}$ Nataraj, S. 1994. Waiting for a connection. Populi 21(10):6-11.

163 Jeyasingh, P., Ramanaiah, T. B. B. S. V., Balasubramaniam, M., Udayakumar, G. S., Kathirvel, S., Ilango, P. and Jayapaul, K. 1985. Teenagers with sexually transmitted diseases. Indian Journal of Sexually Transmitted Diseases 6:12-15.

${ }^{164}$ Durbar Mahila Samanwaya Committee. 1998. The Fallen Learn to Rise: The Social Impact of STD/HIV Intervention Programme. Calcutta.

${ }^{165}$ UNAIDS/WHO. 1998. Epidemiological Fact Sheet on HIV/AIDS and Sexually Transmitted Diseases - India.

${ }^{166}$ Ramasundaram, S. 1997. Tamil Nadu: Blazing a trail. Nexus March-May.

${ }^{167}$ National AIDS Control Organisation. 2000. Policy on HIV Testing. URL: http://www.naco.nic.in/vsnaco/aboutnaco/policies.html

${ }^{168}$ de Zoysa, I., Elias, C.J., MacNeil, J. and Saidel, T. 2000. Current Issues in HIV Counselling and Testing in South and Southeast Asia - A Report. New Delhi: Population Council and Family Health International.

${ }^{169}$ National AIDS Control Organisation. 2000. Clinical Management of HIV/AIDS. URL: http://www.naco.nic.in/vsnaco/program/prog4.html

${ }^{170}$ United Nations Development Programme. 2000. Human Development Report 2000Human Rights and Human Development, New Delhi: UNDP.

${ }^{171}$ Bharat, S. 1999. HIV/AIDS Related Discrimination, Stigmatisation and Denial in IndiaA Study in Mumbai and Bangalore. Mumbai: Tata Institute of Social Sciences.

${ }^{172}$ Maniar, J. K. 2000. Health care systems in transition III. India, Part II. The current status of HIV-AIDS in India. Journal of Public Health Medicine 22(1):33-37.

${ }^{173}$ Indian Institute for Health Management. 2000. Financing Reproductive and Child Health Care in Rajasthan. New Delhi: USAID. 
